\title{
THE CANONS OF CONSTITUTIONAL LAW
}

\author{
J.M. Balkin and Sanford Levinson
}

\begin{abstract}
Academic and political debates about what texts are canonical in the liberal arts have been occurring for some time. In this Commentary, Professors Balkin and Levinson discuss canons and canonicity in the study of law in general and of constitutional law in particular. Canons, they contend, are not simply collections of texts. Skills, approaches, forms of argument, standard examples, and even stock stories can be equally canonical to a discipline or culture. The authors argue that the most significant differences between how canons are formed in law and in the liberal arts stem from differences in institutional context. First, because law schools are professional schools, concerns of pedagogy, cultural literacy, and academic theory diverge more in law than they do in the liberal arts and hence form distinct if overlapping canons. Second, because legal canons rely heavily on pronouncements of courts and legislatures, liberal arts scholars have more control over their canon than do legal scholars. Nevertheless, legal scholars do have some agency in forming their canon, and the authors contend that the canon of constitutional law needs serious revision. The current study of constitutional law is too much centered on the opinions of the Supreme Court and lacks comparative and historical perspective. The narrowness of current canonical materials has had unfortunate effects for constitutional theory and legal education, encouraging too much specialization and focusing attention away from basic questions about the justice of the legal system. A revitalized constitutional canon should pay attention to structural questions that do not often come before courts, and it should include nonjudicial interpreters of the Constitution, particularly representatives of political and social movements whose interpretations often shape and influence the direction of constitutional interpretation.
\end{abstract}

\section{INTRODUCTION}

In March of 1860, Frederick Douglass addressed an audience in Glasgow, Scotland 1 Douglass, the son of a white man and a part-Indian slave, had escaped to freedom, had taught himself to read and write, and by 1860 , had become one of the most prominent abolitionists in the United States. 2 His subject that day in Glasgow was how to interpret the

* J.M. Balkin is Knight Professor of Constitutional Law and the First Amendment, Yale Law School. Sanford Levinson is W. St. John Garwood and W. St. John Garwood, Jr. Regents Chair in Law, University of Texas Law School. We are grateful to Akhil Amar, Bruce Ackerman, John Langbein, Carol Rose, and Reva Siegel for their helpful comments on an earlier draft of this Commentary. A shorter version of this piece will appear as the introduction to a collection of original essays on the legal canon that we are currently editing.

1 Frederick Douglass, Address at Glasgow: The Constitution of the United States: Is It Pro-Slavery or Anti-Slavery? (Mar. 26, 1860), in 2 PhILIP S. Foner, The Life AND Writings of Frederick DOUGLASS 467-80 (1950).

2 See Frederick Douglass, Life and Times of Frederick Douglass, in Frederick Douglass: Autobiographies 453, 526-28, 532, 642-46, 661-64 (Henry Louis Gates, Jr. ed., First Library of Am. College Edition 1996) (1994); Frederick Douglass, My Bondage AND My Freedom 44-45, 113-15, 248-58 (Johnson Publ'g Co. 1970) (1855); Frederick Douglass, NARRATiVe of the Life of Frederick Douglass 16, 40, 57-58, 60 (David W. Blight ed., 1993) (1845); 1 The Life AND Writings of Frederick Douglass, supra note 1, at 11, 16-18; see also William McFeely, Frederick Douglass 8 (1991) (discussing Douglass's racial identity). 
Constitution of the United States. In particular, Douglass asked whether the Constitution protected the institution of slavery or whether, on the contrary, the correct reading of the Constitution made it an antislavery document.

Douglass spoke three years after the Supreme Court's infamous decision in Dred Scott v. Sandford ${ }^{4}$ in which Chief Justice Roger Taney held that American blacks, even free blacks, were not and could not be citizens of the United States 5 Purporting to rely on the original understandings of the persons who framed and ratified the 1787 Constitution, Taney argued that by 1787 a century-long consensus held that blacks "had no rights which the white man was bound to respect and that the negro might justly and lawfully be reduced to slavery for his benefit.' 6 Moreover, Taney insisted, Congress lacked the power to bar slavery in the territories of the United States.7 In Taney's view, the Constitution written by the Framers was clearly pro-slavery.

Douglass disagreed. He did not dispute Taney's reading of American history but insisted that the original intentions of the Framers and ratifiers of the Constitution were irrelevant. The Founders were long dead, "but the Constitution is for ages.' 9 The meaning of the Constitution was to be found in its text, because "only the text, and not any commentaries or creeds written by those who wished to give the text a meaning apart from its plain reading, was adopted as the Constitution of the United States." 10 The Constitution, Douglass argued, "is no vague, indefinite, floating,

3 See Douglass, Life and Times of Frederick Douglass, supra note 2, at 467.

460 U.S. (19 How.) 393 (1857).

5 See id. at 432.

6 Id. at 407.

7 See id. at 451-52. Thus, Taney's opinion in effect ruled unconstitutional the platform of the new Republican Party. See Don E. Fehrenbacher, The Dred Scott Case: Its Significance in AmERICAN LAW AND POLITICS 202 (1978) (indicating that the Republican Party's 1856 platform affirmed the "sovereign powers" of Congress over U.S. territories and declared that Congress should exercise those powers to prohibit slavery in the territories).

8 The Harvard Law Review has informed us that its settled practice is always to refer to Justices of the United States Supreme Court by their ceremonial titles. See A Uniform System of Citation 52 (16th ed. 1996). Thus, we have committed a law review faux pas by referring to "Taney" rather than "Chief Justice Taney" in the above paragraph. Nevertheless, in this Commentary we sometimes depart from the Review's practice for rhetorical reasons. One of our major themes is that constitutional interpretation is much too centered on the worship of the Supreme Court and its pronouncements. The Harvard Law Review's style manual is a wonderful symbol of how pervasive this idolatry has become. One might think that the use of ceremonial titles for Justices was part of a more general practice of respect, but in fact the courtesy seems to be focused particularly on members of the judiciary. Thus, for example, while Roger Taney must always be described as "Chief Justice Taney" in articles appearing in the Harvard Law Review, apparently Abraham Lincoln may be mentioned without adding his ceremonial title of President. We are grateful to the Review for allowing us to depart from its custom in this Commentary, and thereby allowing us to suggest, if only symbolically, that Frederick Douglass is on at least the same level of interpretive authority as Roger B. Taney.

9 Douglass, supra note 1, at 469.

10 Id. Nevertheless, Douglass suggested that there was no serious conflict between text and original understandings, and he emphasized that "the intentions of the framers of the Constitution were good, not bad," with respect to the future of slavery in America. Id. at 473. 
unsubstantial, ideal something, coloured according to any man's fancy, now a weasel, now a whale, and now nothing.' 11 Rather, it is "a plainly written document," "full and complete in itself."12

Nowhere in the text, Douglass pointed out, did the words "slave" or "slavery" explicitly appear 13 Hence, the Constitution could hardly be interpreted as pro-slavery. Indeed, it was antislavery. "In all matters where laws are taught to be made the means of oppression, cruelty, and wickedness," Douglass thundered, "I am for strict construction." 14 Where its text was unclear or open-ended, the Constitution should always be interpreted strictly in favor of maximizing justice and expanding human rights 15 Thus, nothing prevented the Congress or the states from eliminating slavery through legislation. 16

Moreover, Douglass claimed that there were strong textual reasons to think that slavery was itself unconstitutional. "The Constitution," Douglass noted, "forbids the passing of a bill of attainder: that is, a law entailing upon the child the disabilities and hardships imposed upon the parent."17 Hence, "[e]very slave law in America might be repealed on this very ground.' 18

We do not mention Douglass's Glasgow Address merely to promote its particular constitutional arguments, or even to endorse its general approach to constitutional interpretation 19 The question we are concerned with is this: given that Roger Taney's famous remarks in 1857 about the meaning of the Constitution appear and have appeared for decades in American constitutional law casebooks, should Douglass's 1860 Glasgow Address also appear, perhaps in juxtaposition? Is his speech as valuable or as important a presence in constitutional law casebooks as Dred Scott or a dozen other U.S. Supreme Court cases that regularly appear in introductory courses on constitutional law?

Taney's opinion was written by the Chief Justice of the United States, the highest judicial officer in the land. By contrast, Douglass's address was offered by a former slave who - as a result of Dred Scott itself -

11 Id. at 468. Douglass's reference is to Hamlet's mocking of Polonius concerning the appearance of a cloud. See William ShakesPeare, Hamlet act 3, sc. 2, 11. 358-68 (G.R. Hibbard ed., Oxford Univ. Press 1987).

12 Douglass, supra note 1, at 468.

13 See id. at 471.

14 Id. at $475-76$.

15 See id.

16 See id. at 478.

$17 \mathrm{Id}$.

18 Id.

19 We note, however, that Douglass's central interpretive rule — that, "[w]here a law is susceptible of two meanings, the one making it accomplish an innocent purpose, and the other making it accomplish a wicked purpose, we must in all cases adopt that which makes it accomplish an innocent purpose," $i d$. at 476 - has interesting parallels to the theories of contemporary scholars like Ronald Dworkin. See Ronald Dworkin, LaW's Empire 313-14 (1986) (promoting the idea that legal interpretation should make the law "the best it can be"). 
was not even a citizen of the United States, much less a professionally trained lawyer or a government official. Moreover, Taney's opinion, although immediately denounced and vilified by opponents of slavery, was nevertheless the supreme law of the land for a time; it required not one but two constitutional amendments to overrule 20 In contrast, Douglass's Glasgow Address was a political speech that never had any binding legal effect. Indeed, what makes Douglass's speech so interesting is precisely the fact that it was out of step with the consensus of legal opinion of his time. Although many abolitionists surely agreed with Douglass's view that the Constitution prohibited slavery ${ }^{21}$ probably most well-trained lawyers in 1860 , and certainly all those who might have been politically viable candidates for appointment to the federal judiciary, regarded his arguments as specious or "off-the-wall" interpretations of the Constitution 22

But how, precisely, are these facts relevant, if at all? Should either of these two texts, or both, or neither, appear in contemporary constitutional law casebooks?23 Which should American law students study and discuss, which should educated citizens know about, and which should inform the work of legal academics in the present era? Which of these writings, in short, should form part of the "canon" of American legal materials?

To some readers, a discussion of "legal canons" might suggest a treatise on church law, or perhaps, for creative spellers, a discussion of gun control. Our subject is somewhat different. It concerns what is and what ought to be canonical in the study of law. In our view, there is no better

20 The Thirteenth Amendment abolished slavery but did not settle the question of citizenship. See U.S. CONST. amend. XIII. The Fourteenth Amendment guaranteed that all persons born or naturalized in the United States were citizens of the United States and of the state in which they resided. See id. amend. XIV, § 1.

21 See William M. Wiecek, The Sources of Antislavery Constitutionalism in America, 1760-1848, at 269 (1977). The most notable antislavery constitutionalist was Lysander Spooner, who almost certainly influenced some of Douglass's arguments. For a discussion of Spooner's work, see Randy E. Barnett, Was Slavery Unconstitutional Before the Thirteenth Amendment?: Lysander Spooner's Theory of Interpretation, 28 PAC. L.J. 977 (1997).

22 Indeed, even many abolitionists would have agreed that Douglass's arguments were specious, including most prominently the followers of William Lloyd Garrison. Garrison agreed with Taney that the Constitution protected slavery. He denounced it as "a covenant with death, and an agreement with hell" and insisted that the northern states had a moral and political duty to secede from the Union. Walter M. Merrill, Against Wind and Tide: A Biography of WM. Lloyd Garrison 205 (1963).

Douglass began as a Garrisonian, but later broke away; his Glasgow address is a clear rejection both of Garrison's separatist beliefs and of Garrison's pessimism about the practical political meaning of the Constitution. See Douglass, supra note 1, at 478-80; 2 The LifE AND Writings OF Frederick Douglass, supra note 1, at 48-66. For an exchange about the legal and political significance of Douglass's Glasgow Address, see J.M. Balkin, Agreements with Hell and Other Objects of Our Faith, 65 Fordham L. Rev. 1703, 1709-10 (1997), and Dorothy E. Roberts, The Meaning of Blacks' Fidelity to the Constitution, 65 FoRdHAM L. REv. 1761, 1766-69 (1997).

23 In the interest of full disclosure, we report that Douglass's Glasgow Address is currently reprinted in one (and only one) of the standard constitutional law casebooks, a casebook that is, not at all coincidentally, co-edited by one of this Commentary's co-authors. See Paul Brest \& SANFord Levinson, Processes of Constitutional Decisionmaking: Cases and Materials 207-11 (3d ed. 1992). 
way to understand a discipline - its underlying assumptions, its current concerns and anxieties - than to study what its members think is canonical to that discipline. The study of canons and canonicity is the key to the secrets of a culture and its characteristic modes of thought ${ }^{24}$

In the liberal arts, debates about "the Western canon" have been going on for some time, often through controversies about what texts should be assigned in basic humanities courses ${ }^{25}$ Analogous debates about canonicity have occurred in the legal academy too, but by other names and using different vocabularies. They have been debates about interdisciplinarity, about narrative scholarship, about identity politics, about the structure of the law school curriculum, and about the preservation of the liberal precedents of the Warren Court and early Burger Court eras as normative icons. Legal academics have their own ways of discussing what is canonical, even if they never use that particular word.

Questions about legal canonicity have arisen during a time of great excitement and ferment in the American legal academy. In the past twenty-five years, legal scholars have witnessed the entry (some would say invasion) of interdisciplinary approaches, the ascendance of law and economics, the development of feminism, critical race theory, and gaylegal studies, and the increasing influence of both rational-actor methodology and postmodernism. The demographics of the law school have also changed dramatically: more and more women and minorities have attended law schools, and slowly but surely they have gained entry to the ranks of the legal professoriat. Simultaneously, the comparatively insular American law school is "going global." After many years of smug self-assurance, American legal education is finally showing interest in the legal systems and constitutional problems of other countries. To be sure, this newfound concern is partly a means of exporting American legal culture to other

24 The word "canon" comes from the Greek kanon, meaning "rod" or "rule," and originally meant a "rule, law, or decree of the Church." The OXford English Dictionary 838 (2d ed. 1989). Later it came to mean a "standard of judgement or authority [or] a test, criterion, [or] means of discrimination." $I d$. Hence one speaks of the "canons" of polite society. Historically, one of the most important forms of discrimination was the decision whether to count a particular text as Holy Scripture and include it in the Bible. Thus, the word "canon" came to mean a collection that is selected and organized according to a rule or set of rules, like the books of the Bible or the canon of saints in the Catholic Church. Musical canons, for example, are compositions organized according to a strict rule of imitation. See The American Heritage Dictionary of the English language 281 (3d ed. 1992). From these various usages, the word "canon" has acquired the additional connotations of authenticity and sacredness.

25 See David Denby, Great Books: My Adventures with Homer, Rousseau, Woolf, and Other Indestructible Writers of the Western World (1996); Henry Louis Gates, JR., LoOse Canons: Notes on the Culture Wars (1992); Lawrence W. Levine, The Opening of the American Mind: Canons, Culture, And History (1996). A particularly notable (and for some, notorious) debate took place at Stanford University about, among other things, required readings in its basic Western civilization course. See Mary Louise Pratt, Humanities for the Future: Reflections on the Western Culture Debate at Stanford, in The Politics of Liberal Education 13 (Darryl J. Gless \& Barbara Herrnstein Smith eds., 1992). 
lands, but it also reflects an increasing curiosity about how things might be done otherwise here in the United States.

It is precisely at such times of ferment, growth, change, and innovation that anxieties about canons arise in any discipline. The discipline seeks either to reconstitute itself or to close ranks by considering what, if anything, can be said to be canonical about its practices, its methods, or its materials of study. In discussions about the legal canon, analogies to debates that have taken place at Stanford and other universities have proved too tempting to resist.26 After all, the debates at liberal arts colleges have drawn considerable controversy and press coverage, with some of the participants suggesting at times that nothing less than the future of Western civilization depends on accepting their particular position in the debate.

Nevertheless, such comparisons conceal as much as they reveal. In this Commentary, we want to consider both the similarities and the differences in debates over literary and legal canons. More importantly, we want to consider what is really at stake in asking whether any field of law is constituted by a canon. The question of what is canonical must be approached sociologically as well as prescriptively. We cannot debate the content of "the canon" until we understand the purposes for which the question is being asked and the reasons why the question is being asked at a particular moment in the development of legal culture. Moreover, we must understand debates about canons with reference to their particular institutional contexts, for these debates are part of more general forms of ideological and cultural development and struggle. Because we are both teachers of constitutional law, we draw many of our examples in this Commentary from that field, but we hope that the reader will see these as exemplary of more general features of legal canons.

In Part II of this Commentary, we discuss the different ways of constituting or defining a canon. We argue that what is regarded as canonical in law depends very much on the audience for whom and the purposes for which the canon is constructed. For example, legal materials can be canonical because they are important for educating law students, because they ensure a necessary cultural literacy for citizens in a democracy, or because they serve as benchmarks for testing academic theories about the law. Because legal materials have multiple audiences and functions, there is no reason to think that law, or any field of law, has

26 See, e.g., Frances Lee Ansley, Race and the Core Curriculum in Legal Education, 79 CAL. L. REv. 1512, 1513 \& n.3 (1991); Francis J. Mootz III, Legal Classics: After Deconstructing the Legal Canon, 72 N.C. L. REv. 977, 978-80 (1994); Judith Resnik, Constructing the Canon, 2 YALE J.L. \& HumAN. 221, 221 (1990). The constitutional canon was the subject of a 1993 panel at an Association of American Law Schools (AALS) Conference on Constitutional Law at the University of Michigan. See AALS Conference Program, Conference on Constitutional Law (Ann Arbor, Mich., June 12-16, 1993). The more general question "Do We Have a Legal Canon?" was the subject of the plenary session of the 1993 AALS Convention. For a collection of the papers presented at this meeting, see Symposium, Do We Have a Legal Canon?, 43 J. LegAl Educ. 1, 1-26 (1993). 
a single canon. By contrast, different forms of canonicity are more closely linked with one another in the liberal arts than they are in law, and this linkage gives the appearance of a unified canon over which participants fight. Finally, we argue that some of the most important forms of canonicity have less to do with the choice of materials than with the tools of understanding that people use to think about the law — the background structures of "law-talk" that shape conversations within and concerning the law 27 These elements of "deep canonicity" include characteristic forms of legal argument, characteristic approaches to problems, underlying narrative structures, unconscious forms of categorization, and the use of canonical examples.

In Part III, we explain how canonical features of pedagogy and academic theory shape, for good and for ill, how students learn the law and how academics study and theorize about the law. In particular, we contend that the pedagogical canon in constitutional law is much too centered on the opinions of the Supreme Court of the United States. This focus on Supreme Court opinions and the increasing subdivision of the constitutional law curriculum have subtly affected the content of constitutional theory. We also think that, as in the liberal arts, there may be some advantages to expanding the range of materials included in the study of law, but once again we think the reasons for expanding or changing the canon may be different with respect to law and the liberal arts. Part IV is a brief conclusion.

\section{The Different Meanings of CAnonicity}

\section{A. Pedagogy, Cultural Literacy, and Academic Theory}

When we think about debates over the canon in the liberal arts, we normally focus on the question of what books or authors should be assigned and read in university courses. But in fact, many of the books actually assigned in liberal arts courses are collections of pre-selected materials in the form of anthologies. Consider a sampling of the books offered by the Norton Publishing Company: The Norton Anthology of American Literature, ${ }^{28}$ The Norton Anthology of Short Fiction, ${ }^{29}$ The Norton Anthology of English Literature, 30 The Norton Anthology of World Masterpieces, 3 The Norton Anthology of Modern Poetry 32 The Norton

27 For a discussion of the concept of "law-talk," see J.M. Balkin \& Sanford Levinson, Constitutional Grammar, 72 Tex. L. Rev. 1771, 1774-78 (1994).

28 The Norton Anthology of American Literature (Nina Baym, Wayne Franklin, Ronald Gottesman, Laurence B. Holland, David Kalstone, Arnold Krupat, Francis Murphy, Hershel Parker, William H. Pritchard \& Patricia B. Wallace eds., 4th ed. 1994).

29 The Norton Anthology of Short Fiction (R.V. Cassill ed., 3d ed. 1986).

30 The Norton Anthology of English Literature (M.H. Abrams ed., 5th ed. 1986).

31 The Norton ANTHOlogy of World Masterpieces (Maynard Mack ed., 5th ed. 1985) [hereinafter WORLD MASTERPIECES, Fifth Edition]. 
Anthology of Literature by Women: The Tradition in English 3 and The Norton Anthology of African American Literature. ${ }^{4}$ These anthologies save the harried liberal arts professor time and energy both in choosing what books and poems to assign and in editing the chosen works, and that is one reason why they are so popular. Nor is this economy accidental. Offering people ready-made categories to think with and texts to think about are some of the most important functions of canon construction.

This labor saving is due to the work of anthology editors, who carefully screen and select the relevant materials, providing updates as required. In fact, there have been multiple editions of several of these anthologies, suggesting either that the category of "world masterpieces"

\footnotetext{
32 The Norton Anthology of Modern Poetry (Richard Ellmann \& Robert O'Clair eds., 1973).

33 The Norton Anthology of Literature by Women: The Tradition in English (Sandra M. Gilbert \& Susan Gubar eds., 1st ed. 1985).

34 The Norton Anthology of African American Literature (Henry Louis Gates, Jr. \& Nellie Y. McKay eds., 1997).
} 
is not altogether stable 3 ○r, more happily, that new "world masterpieces" are being published every year. $\left.{ }^{3}\right]$

In any case, the editors' decisions as to which among many potential candidates will be canonized in these anthologies may call for exquisite judgment.7 As Sandra Gilbert and Susan Gubar discovered when they published a Norton anthology of literature by women that purported to offer "The Tradition in English,' 38 anthology editors are often subjected to severe criticism, both for their choices and for those choices' pretensions to hegemonic status. 39

35 It is interesting to compare the tables of contents for the fourth and fifth editions of Volume II of the Norton Anthology of World Masterpieces, which includes literature from the seventeenth century to the present. Among the authors present in the fourth edition who are omitted from the fifth are François, Duc de la Rochefoucauld, whose maxims are included, see 2 The Norton Anthology of WORLD MASTERPIECES 128-31 (Maynard Mack ed., 4th ed. 1979) [hereinafter WorLD MASTERPIECES, Fourth Edition], Jean de la Fontaine, see id. at 132-36, Lord Byron, whose Don JuanCanto II is included, see id. at 504-52, François René de Chateaubriand, see id. at 567-88, André Gide, whose The Return of the Prodigal Son is included, see id. at 1371-84, Anna Akhmatova, whose Requiem is included, see id. at 1599-1605, Vladimir Nabokov, whose Cloud, Castle, Lake is included, see id. at 1785-92, Jean-Paul Sartre, whose No Exit is included, see id. at 1793-1825, and Richard Wright, whose Big Boy Leaves Home is included, see id. at 1826-56.

Moreover, some of the authors who are included in both editions are now adjudged to have written different "masterpieces." Thus William Faulkner is represented in the fourth edition by Old Man, see $i d$. at 1648-1720, whereas the fifth edition offers Barn Burning, see 2 WORLD MASTERPIECES, Fifth Edition, supra note 31, at 1781-95, and Spotted Horses, see id. at 1796-1815. Camus's The Renegade, see World MASTERPIECES, Fourth Edition, supra, at 1857-70, is now apparently thought inferior to The Guest, see 2 World Masterpieces, Fifth Edition, supra note 31, at 1895-1906. The fifth edition, moreover, welcomes a host of new authors into the canon, including Jorge Luis Borges, Samuel Beckett, R.K. Narayan, Ralph Ellison, Alexander Solzhenitsyn, Doris Lessing, Alain Robbe-Grillet, Yukio Mishima, Gabriel García Márquez, and Wole Soyinka. See id. at xvi-xvii. All of these authors had published significant work prior to the fourth edition, which was published in 1979, so whatever explains their inclusion, it cannot be the existence of brand new work available to the editors of the 1985 edition.

36 There is also the possibility that textbook publishers like Norton expect their editors to produce new editions every few years or so to undercut the market for used copies of previous editions. This possibility gives new meaning to the expression "marketplace of ideas."

37 See, e.g., Henry Louis Gates, Jr., The Master's Pieces: On Canon Formation and the AfricanAmerican Tradition, in THE POlitics OF Liberal EduCATION, supra note 25, at 95, 107-08.

38 The Norton Anthology of Literature by Women: The Tradition in English, supra note 33 (emphasis added). Perhaps in response to criticism, the title of the second edition has been slightly altered. See The Norton Anthology of Literature by Women: The Traditions in English (Sandra M. Gilbert \& Susan Gubar eds., 2d ed. 1996).

39 For example, Gail Godwin complained that Gilbert and Gubar gave too much space to "littleknown works of significant feminist content" while neglecting women writers "whose prose or poems do not always deal with female experience or lend themselves to feminist explication." Gail Godwin, One Woman Leads to Another, N.Y. TIMES, Apr. 28, 1985, § 7, at 13. Thus, according to Godwin, the anthology should have been subtitled "The Feminist Tradition" rather than "The Tradition" of women writers in English. Id. Joyce Carol Oates noted that the anthology "had the perhaps unanticipated effect of polarizing women into two contending camps: those who denied the claims of gender and those who acknowledged them." Joyce Carol OAtes, (Woman) Writer: OcCASIONS AND OpPORTUNitiEs 30 (1988). Criticisms of the anthology, Oates suggested, sometimes came from "women writers whose sense of themselves is 'genderless,' though their writing has been aimed toward a specifically female audience and their literary reputations nourished, in large part, by feminist support." Id. 
Law professors also rely on anthologies, though we call them "casebooks." Indeed, it is safe to say that no part of the academy relies more on anthologies than do American law schools. Energetic law professors sometimes add supplemental materials of their own devising and may even recommend a hornbook or two, but for the most part American law students are fed a steady diet of increasingly thick (and increasingly expensive) casebooks ${ }^{40}$

Just as literature professors decide what poems and novels to teach, editors of casebooks decide what "cases and materials" students ought to be exposed to on their intellectual journey from uninitiated laypersons to well-educated, "disciplined" lawyers. We have no doubt that the purposes and agendas of the people who create these collections often differ; we are equally certain that the academy would benefit from a far more explicit (and contentious) debate than the present muffled discussion about what visions of law underlie any given casebook. Thus, one purpose of this Commentary is to provoke a long overdue discussion among would-be constructors of the legal canon about the reasons for their particular decisions - a discussion not simply about what texts they include and exclude, but also about why these texts are included or excluded 4

We begin, however, with a legal document that generates no contention at all: John Marshall's opinion in McCulloch v. Maryland, ${ }^{12}$ which established an expansive view of national power under the U.S. Constitution. At least within the field of constitutional law, almost everyone seems to agree that $M c C u l l o c h$ is canonical. Indeed, in a recent study of eleven major constitutional law casebooks entitled "Is There a Canon of Constitutional Law?," McCulloch was one of only ten cases included in all of the casebooks. ${ }^{43}$ This unanimity only confirms the

40 We emphasize American practice here, for in Great Britain and continental Europe (as elsewhere), American-style casebooks have not caught on so readily. Often, professors in these countries assign their students treatises or simply give them lists of cases and statutes to find in the library and send them on their merry way.

41 Although this debate is long overdue, it is not unprecedented. See Christopher D. Stone, Towards a Theory of Constitutional Law Casebooks, 41 S. CAL. L. REV. 1 (1968). More recently, there have been occasional discussions about the role of race in the legal curriculum, see, e.g., Ansley, supra note 26 , at $1515 \& \mathrm{n} .8$, about the gendered selection of materials in contracts casebooks, see, e.g., Mary Joe Frug, Re-reading Contracts: A Feminist Analysis of a Contracts Casebook, 34 AM. U. L. Rev. 1065, 1076-1113 (1985), and about the presuppositions underlying the structure of civil procedure casebooks, see, e.g., Linda S. Mullenix, God, Metaprocedure, and Metarealism at Yale, 87 Mich. L. Rev. 1139, 1556-65 (1989). There is even a literature discussing the famous Hart and Wechsler approach to federal jurisdiction. See Akhil Reed Amar, Law Story, 102 Harv. L. Rev. 688 (1989) (reviewing Paul Bator, Daniel J. Meltzer, Paul J. Mishin \& David L. Shapiro, Hart and Wechsler's The Federal Courts and the Federal System (1988)); Richard H. Fallon, Jr., Comparing Federal Courts "Paradigms," 12 Const. Commentary 3 (1995); Michael Wells, Who's Afraid of Henry Hart?, 14 CONST. COMMENTARY 175 (1997).

4217 U.S. (4 Wheat.) 316 (1819).

43 See Jerry Goldman, Is There a Canon of Constitutional Law?, Am. PoL. SCI. Ass'N NewsL. (Law and Courts Section of the Am. Political Science Ass'n), Spring 1993, at 2-4. Goldman's list of truly canonical cases, see id. at 3, is as follows (in alphabetical order): 
intuition that every law student should be exposed to McCulloch and should be able to offer some informed commentary about its holding and arguments. ${ }^{14}$ Yet articles about $M c$ Culloch rarely appear in American law

(1) Brown v. Board of Educ., 347 U.S. 483, 495 (1954) (holding segregation of public schools unconstitutional).

(2) Garcia v. San Antonio Metro. Transit Auth., 469 U.S. 528, 555-57 (1985) (upholding federal regulation of state employees under the Commerce Clause).

(3) Gibbons v. Ogden, 22 U.S. (9 Wheat.) 1, 221-22 (1824) (construing the Commerce Clause and defining the concept of interstate commerce).

(4) Griswold v. Connecticut, 381 U.S. 479, 485-86 (1965) (recognizing the constitutional right

to privacy and striking down a law banning the sale of contraceptives to married persons).

(5) Lochner v. New York, 198 U.S. 45, 64-65 (1905) (striking down a maximum hour law for

bakery employees).

(6) Marbury v. Madison, 5 U.S. (1 Cranch) 137, 177-80 (1803) (invoking the power of judicial review over congressional legislation).

(7) McCulloch v. Maryland, 17 U.S. (4 Wheat.) 316, 425 (1819) (upholding the constitutionality of the Second Bank of the United States).

(8) New York Times Co. v. United States (The Pentagon Papers Case), 403 U.S. 713, 714 (1971) (per curiam) (rejecting a request for an injunction against the publication of materials claimed to compromise national security interests).

(9) Roe v. Wade, 410 U.S. 113, 164-67 (1973) (extending the right of privacy to a woman's right to abortion).

(10) Youngstown Sheet \& Tube Co. v. Sawyer, 343 U.S. 579, 582, 588-89 (1952) (striking

down President Truman's seizure of steel mills as violating the separation of powers).

Goldman notes, incidentally, that if he had omitted the casebook with the fewest cases (BREST \& LEVINSON, which currently does not feature full coverage of the First Amendment), at least five additional cases would have been added to the list of ten cases common to all eleven of the surveyed books, see id. at 4:

(11) Dennis v. United States, 341 U.S. 494, 516-17 (1951) (upholding the convictions of leaders of the Communist Party for conspiring to attempt to teach the necessity of the violent overthrow of the U.S. government).

(12) Heart of Atlanta Motel, Inc. v. United States, 379 U.S. 241, 261-62 (1964) (upholding the

Civil Rights Act of 1964 under Congress's power to regulate interstate commerce).

(13) Miller v. California, 413 U.S. 15, 24 (1973) (offering a three-part test for the definition of obscenity).

(14) New York Times Co. v. Sullivan, 376 U.S. 254, 288-92 (1964) (establishing a constitutional standard for state defamation law).

(15) NLRB v. Jones \& Laughlin Steel Corp., 301 U.S. 1, 30-32, 49 (1937) (upholding the National Labor Relations Act as a proper exercise of Congress's power to regulate interstate commerce).

Finally, as Goldman notes, there are three other likely candidates included in BREST \& LEVINSON but omitted by one of the other books surveyed, see id. at 3-4:

(16) Plessy v. Ferguson, 163 U.S. 537, 551-52 (1896) (upholding the "separate but equal" doctrine as applied to the segregation of railway carriages traveling intrastate).

(17) Home Bldg. \& Loan Ass'n v. Blaisdell, 290 U.S. 398, 447-48 (1934) (upholding a

Minnesota mortgage moratorium law as consistent with the Contracts Clause).

(18) The Slaughterhouse Cases, 83 U.S. (16 Wall.) 36, 74 (1873) (construing the Privileges or Immunities Clause of the Fourteenth Amendment narrowly to apply only to rights of national citizenship).

44 It is worth noting that Daniel A. Farber, William N. Eskridge, Jr., and Philip P. Frickey, in their self-consciously presentist Cases and Materials on Constitutional Law: Themes for the Constitution's Third Century (which was not included in Goldman's survey), devote a dozen pages to McCulloch, even given their successful attempt to create a casebook that is far shorter than any of their competitors. See Daniel A. Farber, William N. Eskridge, JR. \& Philip P. Frickey, Cases and Materials on Constitutional LaW: Themes for the Constitution's Third Century 774-86 (1993). The book is 1206 pages long, including the preface, the tables of contents, and the cases, end materials, and index. More typical is the most recent edition of what is said to be the most widely adopted casebook 
reviews 45 If one attempted to determine what is canonical by examining the work product of legal academics as revealed in American law reviews, McCulloch would leave almost no traces at all.

In short, we may find a wide divergence between what professors of law teach and what they write about. Liberal arts professors are in a somewhat different position. Contrast the law professor's treatment of McCulloch with the literature professor's treatment of Shakespeare's plays. These plays are not only taught to the young, but also continue to be written about with great zeal by many important members of the literary academy, even - and perhaps especially — when these scholars apply trendy contemporary methods of interpretation like deconstruction, the new historicism, and Lacanian psychoanalytic theory. ${ }^{16}$ Methodologies wax and wane, but each one gets applied to Shakespeare in turn.

What is "canonical" in law varies according to how the canon is defined, and how the canon is defined depends on the purpose of the canon. For example, consider three different ways that the question of the canon might be articulated in the field of constitutional law. First, we might ask what key cases and materials should be taught in constitutional law courses and reprinted in constitutional law casebooks. We call this the "pedagogical canon." Second, we might ask what key cases and materials any educated person should be aware of in order to participate in serious discussions about American constitutional development. We call this the "cultural literacy canon." Third, we might ask what key cases and materials any serious legal academic — as distinguished from the ordinary lawyer or the well-educated generalist - should know and any serious theory of constitutional law must take into account. We call this the "academic theory canon."

The example of McCulloch suggests that these canons can and do diverge. In designing a casebook, an editor concerned with preparing

in the field, Geoffrey R. Stone, Louis M. Seidman, Cass R. Sunstein \& Mark V. Tushnet, Constitutional LaW (3d ed. 1996), which totals 1917 pages and devotes only two more pages to McCulloch than does the Farber casebook, see id. at 57-71. Both the Farber and the Stone casebooks edit McCulloch. Paul Brest and Sanford Levinson are unique in reprinting an unedited version of the case. See BREST \& LEVINSON, supra note 23, at 19-31, 42-47.

45 Moreover, contemporary legal scholars rarely find it necessary to explain or justify McCulloch. However, the powerful surges of political conservatism we are currently witnessing in America soon may change all that. The changing political currents of our age have opened a space for increasingly radical positions on the rights and powers of states and have emboldened both judges and academics to make federalism arguments that would have been roundly dismissed as extreme only a few decades ago, even by many conservatives. See Printz v. United States, 117 S. Ct. 2365, $2383-84$ (1997); U.S. Term Limits, Inc. v. Thornton, 514 U.S. 779, 845-926 (1995) (Thomas, J., dissenting); United States v. Lopez, 514 U.S. 549, 584-602 (1995) (Thomas, J., concurring); Randy E. Barnett, Necessary and Proper, 44 UCLA L. ReV. 745, 758-59, 788-93 (1997); Gary Lawson \& Patricia B. Granger, The "Proper" Scope of Federal Power: A Jurisdictional Interpretation of the Sweeping Clause, 43 DUKE L.J. 267, 271-74 (1993).

46 See, e.g., Stephen J. Greenblatt, Learning to Curse: Essays in Early Modern Culture 80-98 (1990); Stephen Greenblatt, Shakespearean Negotiations: The Circulation of Social ENERGY IN RENAISSANCE ENGLAND passim (1988). 
lawyers to litigate contemporary issues might choose to focus on current issues in constitutional law at the expense of those cases and materials that contribute to cultural literacy. For example, we assume that, as a matter of cultural literacy, students of the Constitution (and of the Supreme Court) should know something about Dred Scott v. Sandford - a case that helped precipitate a civil war. This is so even though Dred Scott is almost completely irrelevant to contemporary constitutional litigation. Similarly, many cases and materials that are valuable for the purpose of cultural literacy are not necessarily crucial for any serious academic theory to explain. Few constitutional scholars believe that the principles or the holding of Dred Scott are important for modern constitutional theory (except perhaps as a symbol continually to be vilified) 47

\section{B. Audience and Function}

Each of our formulations of a canon of constitutional law implicitly assumes an "audience" for the canon. The audience is the group of persons who are supposed to be edified or instructed by the canon or (in the case of the academic theory canon) who are supposed to utilize the canon as a set of standard problems or materials that need to be explained and justified. Our earlier description of the pedagogical canon, for example, presumed that the appropriate audience was law students; our definition of the theoretical canon assumed that the relevant audience was legal academics. But these are not the only possible choices, and as we vary the intended audience for a given canon, the canon's contents may also vary. The key cases and materials of constitutional law that every political scientist should know, for example, are not necessarily the same ones that we should expect ordinary citizens to be familiar with.

Moreover, the contents of a canon may vary depending on the appropriate function of that canon for a particular audience. Consider the pedagogical canon, for example. What precisely are we law professors preparing our students to do? If we are concerned only with preparing students for everyday law practice, should we care whether students know about Prigg v. Pennsylvania ${ }^{48}$ in which Pennsylvania tried to create due process protections for blacks accused by slave catchers of being fugitive slaves? 49 After all, as many students who are assigned Prigg are quick to point out, slavery has long been outlawed in this country. Spending time on an 1842 case obviously means less time to spend on the latest

\footnotetext{
47 This vilification comes especially from contemporary "originalists" who are naturally eager to disassociate themselves from the self-consciously originalist methodology adopted by Taney. See, e.g., Robert H. Bork, The Tempting of America: The Political Seduction of the Law 28-34 (1990) (finding in Dred Scott the origins of an illegitimate and undesirable substantive due process).

4841 U.S. (16 Pet.) 536 (1842).

49 See id. at 550-55 (discussing the text of the 1826 Pennsylvania "Act to give effect to the provisions of the Constitution of the United States relative to fugitives from labour, for the protection of free persons of color, and to prevent kidnapping").
} 
pronouncements from the Supreme Court, which are far more likely to interest the judges before whom our students may someday practice. Indeed, if preparation for the practical realities of legal practice is the central aim of pedagogy, then why should law students spend so much time on constitutional issues at all, given that most students will rarely be confronted with such issues?

If law professors think it important to introduce their students to nonbusiness-related topics of constitutional law — or, to put it another way, if these topics properly form part of the pedagogical canon for law students - then it must be at least in part because legal educators believe that lawyers perform (or ought to perform) a special "citizenship" function in a democracy. Presumably this citizenship function requires that lawyers know something about the basic foundations of the American legal system, including the U.S. Constitution. Hence, legal educators, as the teachers of lawyers, should structure their courses with this role in mind. Of course, when the functions of the pedagogical canon are fixed in this way, it overlaps predictably with the canon of cultural literacy.

Next, consider the possible functions served by the cultural literacy canon - the materials that any educated person should know about in order to participate in and contribute to serious general discussions about American law. It is important to recognize that these discussions are usually normative rather than merely descriptive, especially when conducted among Americans themselves; they often concern whether America is in fact well served by particular aspects of its law and whether certain radical changes might not be desirable.

In addition, people may think that cultural literacy in constitutional matters is important because it fosters pride in and attachment to the American political community. At least some cases may form part of the canon because they seem to promote an appealing portrait of "Americathe-good." Moreover, the desire to engender pride may lead to the omission of certain cases and legal events from the cultural literacy canon because they present a less attractive picture of the rule of law in the United States.

On the other hand, if the function of cultural literacy is to help us learn from America's past misdeeds and mistakes and to understand how these have irrevocably shaped the world in which we live today, we might include a different selection of cases and materials: for example, cases and materials about slavery, Jim Crow, controls on the immigration and liberties of Chinese laborers, and the mistreatment of Native Americans. Such a cultural literacy canon might supplement presumably affirmative icons like Brown v. Board of Education 5 and New York Times Co. v.

50347 U.S. 483 (1954). 
Sullivan ${ }^{51}$ with less inspiring cases like Dred Scott, United States v. Debs, ${ }^{2}$ Korematsu v. United States 53 and The Chinese Exclusion Case 5

The theoretical canon may have still other functions. It prescribes the materials that constitute the central foci of professional constitutional theorists. That is, it concerns the materials that a young assistant professor ought to study if he or she wants recognition as an active participant in the field.55 Because this function of the academic theory canon is so closely linked to the quest for disciplinary solidarity, status, and respect within the profession of legal academics, we should not be surprised that it differs

51376 U.S. 254 (1964).

52249 U.S. 211 (1919). Debs upheld a conviction on the ground that Debs's remarks implied that he approved of conscientious objection to the draft in violation of the Espionage Act of 1917. See id. at 216-17. Because of the fortuity that Oliver Wendell Holmes coined the clear and present danger test in the companion case of Schenck v. United States, 249 U.S. 47, 52 (1919), Schenck almost always has pride of place in casebooks, with Debs sometimes relegated to a footnote. See, e.g., William Cohen \& Jonathan D. Varat, Cases and Materials on Constitutional LaW $1200-01$ \& n.2 (10th ed. 1997) (describing Debs simply as "a prominent socialist").

Thus, we wonder how many students never learn that the United States imprisoned Eugene V. Debs, undoubtedly the most important socialist leader of his time, who amassed almost six percent of the vote (over 900,000 votes) for the presidency in the 1912 election (and who received roughly the same number of votes in 1920 while he was serving a ten-year sentence that had been unanimously upheld by the Supreme Court). See Brest \& LEVINSON, supra note 23, at 330-32; The REAdER's Companion to American History 270 (Eric Foner \& John A. Garrity eds., 1991); Stone, Seidman, Sunstein \& TusHNET, supra note 44, at 1096-97. Instead, the emphasis on Schenck and on Abrams v. United States, 250 U.S. 616 (1919), leads many students to assume that the governmental oppression of dissidents was indeed restricted to what Holmes memorably called "puny anonymities," id. at 629 (Holmes, J., dissenting). We therefore think that there are good reasons to reverse the treatment accorded to Schenck and Debs, even in those casebooks that currently recognize Debs's significance, see Gerald Gunther \& KathleEn M. Sullivan, Constitutional Law 1038-40 (13th ed. 1997); William B. Lockhart, Yale Kamisar, Jesse H. Choper, Stevenen H. Shiffrin \& Richard H. Fallon, JR., Constitutional Law 617-18 (8th ed. 1996); Stone, Seidman, Sunstein \& Tushnet, supra note 44, at 1096-97. The Lockhart casebook appropriately quotes Harry Kalven's statement that, "[t]o put the case in modern context, it is somewhat as though George McGovern had been sent to prison for his criticism of the [Vietnam] War." LOCKHART, KAMISAR, ChOPER, SHIFFrin \& FAllon, supra, at 617 n.a (second alteration in original) (quoting Harry Kalven, Ernst Freund and the First Amendment Tradition, 40 U. CHI. L. REv. 235, 237 (1973)) (internal quotation marks omitted). Of course, their very need to identify the war in brackets also suggests that soon most of our students will need to be told who George McGovern was.

53323 U.S. 214 (1944). Korematsu upheld the constitutionality of wartime internment of JapaneseAmerican citizens. See id. at 223-24.

54 Chae Chan Ping v. United States (The Chinese Exclusion Case), 130 U.S. 581 (1889). The Chinese Exclusion Case upheld the plenary power of the federal government to expel Chinese aliens working as laborers in the United States. See id. at 610-11.

55 We have previously considered one aspect of this subject in our commentary on Fred Shapiro's list of the 100 most-cited law review articles of all time. See J.M. Balkin \& Sanford Levinson, How To Win Cites and Influence People, 71 ChI.-Kent L. Rev. 843, 854-56, 860-66 (1996) (discussing Fred R. Shapiro, The Most Cited Articles Revisited, 71 ChI.-Kent L. Rev. 751 (1996)). We have suggested, for example, that someone wishing to become a "player" in the legal academy is well advised to become adept in the jurisprudence of the First and Fourteenth Amendments, rather than to study and write about the power of the President to engage in foreign adventures without prior approval of Congress. See id. at 854-56. Whether this allocation of energies is socially useful is quite another question. But there is no reason to think that canons are always socially useful, at least outside the confines of their respective disciplines. 
greatly from the pedagogical canon directed at fledgling lawyers. The legal academy has become increasingly interdisciplinary, even as law schools still perform their traditional professional function of training future members of the bar. As a result, the audience for legal scholarship has increasingly become other legal academics rather than students (the audience for the pedagogical canon) or fellow citizens (the presumed audience for the cultural literacy canon).

The academic theory canon today certainly includes "materials" as well as "cases"; more importantly, it increasingly includes the work of nonlegal academics. Some familiar examples include the works of the philosopher John Rawls and the economist Ronald Coase.56 Even though neither of these scholars is a lawyer, ignorance of their work would be a sign of incompetence in a law professor who taught in certain fields. Indeed, we suspect that the work of Rawls and Coase is more canonical - at least within the world of legal academics striving for professional success than many clearly legal materials, such as the Supreme Court's opinion in Prigg v. Pennsylvania.

This is, of course, an empirical claim, and one might try to prove it by laboriously counting citations in articles published in "leading" law journals (like the Harvard Law Review). Indeed, Fred Shapiro has done precisely this, and he determined that the most frequently cited article of all time in articles published in legal journals (and presumably directed at legal academics) is Coase's The Problem of Social Cost 57 Because Shapiro did not count citations to books, we do not know the actual frequency of citations to Rawls's A Theory of Justice, but we would place a substantial bet that it shows up very frequently indeed.

Yet a simple thought experiment should prove equally convincing. Canonicity is not simply a matter of what one thinks important; it is also a matter of what one thinks others think important. In his classic academic novel Changing Places, David Lodge describes the academic's game of "Humiliation," in which a player names a work that he or she has not read and wins a point for every other person who has.58 The winner of the game is the person best able to demonstrate how ignorant he or she is, as judged by the collective reading habits of his or her colleagues. Hence, winning requires a knowledge both of what one has read (and not read) and of what others are likely to think important enough to read. Lodge describes an especially competitive young member of the Euphoric State University English Department who could not resist one-upping everyone

\footnotetext{
56 See, e.g., John Rawls, Political Liberalism (1993); John Rawls, A Theory of Justice (1971); R.H. Coase, The Problem of Social Cost, 3 J.L. \& Econ. 1 (1960).

57 See Shapiro, supra note 55, at 759, 767.

58 See David Lodge, Changing Places: A Tale of Two Campuses 135 (Penguin Books 1992) (1975).
} 
by admitting that he had never read Hamlet.59 $\mathrm{He}$ won the game, though he was later denied tenure as a consequence 6

One way to construct a theoretical canon for academics, then, is by playing an imaginary game of "Humiliation." The "winner" would be the person who has failed to read works in the operative canon. Thus, to understand the current role of interdisciplinary scholarship in the academic theory canon, ask yourself which would be the greater academic embarrassment to a law professor: to confess, at a professional gathering, that you had not read A Theory of Justice or The Problem of Social Cost, on the one hand, or Prigg v. Pennsylvania, on the other 61

As this example suggests, the canon of interest to academics may be quite different from the canon that is important to the practicing lawyer. 52 One reason for significant differences in canon formation among various socio-legal groups is that each group constitutes a different community with different interpretive assumptions, purposes, and practices. Thus, an increasing divergence in canon construction among these groups may be a symptom of an increasing division among interpretive communities and an increasing differentiation in purposes among academics, lawyers, and judges (in addition to the professional differentiation that has always existed between lawyers and citizens). Each interpretive community may have its own canon (or set of canons), and although these canons surely overlap, they may also diverge in particular respects.

This divergence suggests a point that we shall return to later in this Commentary. One reason for renewed interest in canons and in questions of canonicity may be a desire to reestablish commonality within an imagined interpretive community of judges, lawyers, and academics that many fear is falling apart 63 Enforcement of canons is invariably a sort of

59 See id. at 136.

60 See id.

61 Other readers might imagine which admission of ignorance would be less harmful to give to a law school appointments committee, or which would be less damaging if placed in one's tenure file. With suitable amendment, the game can be employed to discern the canon of cases and materials that any practicing lawyer should know. For example, imagine the following exchange at an oral argument:

Federal judge: Well, that's a very interesting argument, counselor, but doesn't it conflict with

Marbury v. Madison?

Lawyer: Uh-oh.

62 The canon of interest to academics may also differ from the canon that is important to a judge seeking competent law clerks. See Harry T. Edwards, The Growing Disjunction Between Legal Education and the Legal Profession, 91 MicH. L. REv. 34, 34-42 (1992) (arguing that the gap between legal academics and judges should be bridged by means of "practical" scholarship that combines theory with doctrine); Sanford Levinson, Judge Edwards' Indictment of “Impractical” Scholars: The Need for a Bill of Particulars, 91 Mich. L. REv. 2010, 2012-18 (1993) (agreeing with Judge Edwards that a gap between academics and the legal profession exists, but disagreeing with Judge Edwards's conclusions).

63 This certainly seems to be the basis of Judge Edwards's heartfelt attack on the contemporary legal academy. See Mary Ann Glendon, A Nation Under Lawyers: How the Crisis in the Legal Profession Is Transforming American Society 199-229, 288 (1994); Edwards, supra note 62 , at 61-63. 
policing action, no matter how benign its motivations, ${ }^{4}$ and police often step up their vigilance when they fear that social order is breaking down.

\section{Canons Legal and Literary}

We have argued that there are multiple canons in law that vary by audience and function. There are multiple ways of defining the canon and there are multiple interpretive communities that might each have a canon, each of which is increasingly separated from the others. Recognizing these features of legal culture helps us understand why comparisons to debates about the canon in English literature and in the liberal arts generally are especially likely to be misleading.

First, in the liberal arts, the pedagogical canon is very often closely linked to the cultural literacy canon and the academic theory canon. The question of what one should teach in English departments is very much connected to the questions of what educated people should know, what the "best" literature is (including what literature has the best effects on its readers), what literary works every theory of artistic greatness must take into account, and what sorts of things (including works of literature) literary critics should write about. Many (but certainly not all) liberal arts educators see the function of cultural literacy - the notion that every educated person should know something about Dante or (from a different perspective) should be exposed to literature describing racial oppression as directly connected to the pedagogical goal of producing edified, if not virtuous, people. Just as William Bennett thinks that exposing youngsters to classic literature will produce better citizens 65 so too his critics on the left seek to introduce novels and poems about race and gender to edify and enlighten their educational charges.

In short, we strongly suspect that the pedagogical, cultural literacy, and academic theory canons are more closely linked in debates about the canon in liberal arts curricula than they are in academic law. Transferring these debates root and branch into the legal milieu is likely to confuse the issue. As scholars who have explored analogies between artistic and legal modes of thought, $\sqrt{66}$ we think it important to emphasize that one cannot usefully explore these analogies without noting significant differences where they arise. Analogies to debates about the literary canon can be helpful only if

64 There is a reason, after all, that one refers to "disciplines." See the discussion in J.M. Balkin, Interdisciplinarity as Colonization, 53 WASH. \& LEE L. REV. 949, 952-57 (1996). We have made a similar point in evaluating Philip Bobbitt's claim that constitutional lawyering is constituted by the use of a given legal grammar. See Balkin \& Levinson, supra note 27, at 1775 (positing that Bobbitt is a "grammarian of our constitutional culture, determined to identify - and to police - the boundaries of what counts as the particular . . . language of constitutional 'law talk"').

65 See William J. Bennett, The Book of Virtues: A Treasury of Great Moral Stories 11 (1993) ("This book ... is a 'how to' book for moral literacy."),

66 See, e.g., Sanford Levinson \& J.M. Balkin, Law, Music, and Other Performing Arts, 139 U. PA. L. REV. 1597 (1991). 
we separate out issues that literary debates may tend (for institutional reasons) to collapse.

A second difference follows from the first. English professors, unlike law professors, do not usually offer badly written or badly reasoned literature in their courses to provoke discussion. ${ }^{7}$ Law professors, however, regularly include such literature in their pedagogical canon. Legal casebooks in the United States often contain cases that the casebook authors think are wrongly decided or, even if the correct result is reached, offer styles of reasoning that the authors wish to question or criticize. First-year textbooks, especially in the common law subjects, often feature seemingly contradictory sets of cases and materials selected to introduce competing policy considerations or otherwise stimulate discussion and provoke thought. It follows that, for sound educational reasons, the pedagogical canon of cases to which law students should be exposed may contain something more than the academic theory canon of materials that any sound legal theory must discuss and explain 68

In fact, law professors routinely include cases and materials that are not only badly reasoned, but also unjust, because they are insensitive to the poor and oppressed, because they justify violations of civil liberties, or because they are racist or sexist. Plessy v. Ferguson 69 which gave constitutional blessing to Jim Crow, 70 is probably the canonical example of such a case. English professors sometimes do offer texts that they regard as racist and sexist, but usually not in order to enshrine them in the canon. Rather, the point is to reveal the racism and sexism of what is currently regarded as canonical. Indeed, one senses an urge in some quarters to boot out of the canon (or at least deemphasize) famous works now viewed as irredeemably racist or misogynist.

Perhaps the most striking difference between the legal and literary academies is institutional. An important part of the canons of law consists of the authoritative materials produced by courts and legislatures. These institutions strongly influence the content of what law professors teach and law students learn. For example, it would be rather extraordinary if a casebook on welfare rights law omitted the Welfare Reform Act of 1996 simply because the authors found it normatively dreadful or stylistically objectionable. Indeed, a law teacher who completely neglected the pronouncements of legislatures and courts would not simply be idiosyncratic; she would be committing professional malpractice.

\footnotetext{
67 An advanced course may offer what we today believe to be badly written material, but the purpose would be to reveal the vast differences in taste and sensibility between the earlier age and our own.

68 Conversely, the pedagogical canon may contain far fewer of the materials that legal academics debate in their own work, because pedagogical considerations (plus the sheer scarcity of time) often prevent a law teacher from assigning the entire theoretical canon in a course.

69163 U.S. 537 (1896).

70 See id. at $550-51$.
} 
By contrast, the literary academy has no single institution or set of institutions that successfully proclaims its right to produce new texts that must become the object of close study by literary academics or its right to offer singularly authoritative interpretations of "classic" texts. The denizens of certain literature departments may well think of themselves as "supreme" and of members of other literature departments as "inferior." 1 They may regard their own work as authoritative and insist that it be accepted by those they consider lesser lights. But even the most megalomaniacal of these professors will concede that, for better or worse, no official designation of authoritative interpretations exists. No scholar or group of scholars can plausibly claim a right "ultimately" to decide whether Hamlet was feigning madness or what William Blake really meant in his famous poem on the tiger 72 Nor can any "literary legislature" publish poems or novels that automatically become the central focus of the academy.

Law, on the other hand, is blessed - or afflicted, depending on one's point of view - by institutions that proclaim the privileged status of their own pronouncements. This is the most obvious reason why judicial opinions (and especially U.S. Supreme Court opinions) dominate American legal casebooks. Few legal academics now believe that the individuals who comprise the Supreme Court are so wise that their views deserve pride of place over the views of academics. (In any case, the opinions of judges are increasingly written by their clerks, who are barely a year out of law school.) Some law professors even insist that the Supreme Court's pronouncements are not authoritative as to the true meaning of the Constitution.73 But all of these scholars spend valuable time in their classes and use up valuable space in their teaching materials studying the pronouncements of that Court. It is almost impossible, as a practical matter, to overcome the view that the Constitution is what the Supreme Court says it is and that the law is what courts, legislatures, and administrative agencies say it is.

It would be easy and wrong, we think, to explain this difference solely on the ground that the study of law is the study of power and the study of literature is not 74 There is plenty of power at stake in any academic

71 Cf. U.S. Const. art. III, $\S 1$ (distinguishing the Supreme Court from "such inferior Courts as the Congress may from time to time ordain and establish").

72 Cf. Cooper v. Aaron, 358 U.S. 1, 18 (1958) (asserting the supremacy of the judiciary and of the Supreme Court in matters of constitutional interpretation). For a recent defense of such hierarchical superiority in the law, see Larry Alexander \& Frederick Schauer, On Extrajudicial Constitutional Interpretation, 110 HARV. L. REV. 1359, 1372-86 (1997).

73 See, e.g., SANFord Levinson, Constitutional Faith 9-53 (1988); Michael Stokes Paulsen, The Most Dangerous Branch: Executive Power To Say What the Law Is, 83 Geo. L.J. 217, 220-22 (1994).

74 This distinction is, of course, a familiar trope in the study of law and literature. See, e.g., Robin L. West, Adjudication Is Not Interpretation: Some Reservations About the Law-as-Literature Movement, 54 Tenn. L. Rev. 203, 205, 207 (1987); cf. Robert M. Cover, Violence and the Word, 95 Yale L.J. 1601, 1609-10 (1986) (asserting that adjudication involves a violence that is "utterly real," as opposed 
institution. Careers are made and destroyed, reputations are elevated and besmirched, funds are raised and distributed, and the minds of students are refined or coarsened. The substantial power that can be exercised through the seemingly harmless "pursuit of knowledge" is a major reason why contemporary critics of the academy are so alarmed by what occurs within its ivory towers. The question is not the presence or absence of power, but the form of that power and the ways in which that power is organized. The study of the legal system in the United States is organized around institutions that are separate from the academy and can claim canonical status without the help of the professors who study them. We doubt that any set of political or cultural institutions has the same relationship to the work of liberal arts professors.

\section{Deep Canonicity}

We can approach the question of canonicity in yet another way. Our three examples of canons in constitutional law presume that what makes a legal canon canonical are "cases and materials," in the same way that the Western canon is a collection of particular books, plays, and poetry. Yet educators who defend the Western canon are not interested in these manuscripts merely for their own sake; they want students to read them because they will introduce students to basic approaches and questions that have been central to Western culture from the Greeks onward. This suggests a very different notion of canonicity: the canonicity of certain ways of thinking, talking, and arguing that are characteristic of a culture. We call these forms of thinking, talking, and arguing "deep canonicity." 55 They are an important part of what makes canons constitutive of a particular culture or a particular discipline. For convenience, we note four different forms of deep canonicity.

1. Canonical Arguments. - The first form of deep canonicity consists of the kinds of arguments that members of a particular culture or a particular discipline characteristically employ. Philip Bobbitt, for example, argues that American constitutional culture is distinguished and legitimated by its characteristic forms of argument.76 Bobbitt claims that six modalities - textual, structural, historical, prudential, doctrinal, and ethical — underlie all constitutional interpretation; that each mode of argument is of equal constitutional status; and that following these modalities — and no others - gives constitutional argument its legitimacy.7 We are somewhat skeptical of Bobbitt's claims about exclusivity and legitimacy; yet we think that his general approach to legal

to the violence found in literature). For a critique of this distinction in the context of musical performance, see Levinson \& Balkin, supra note 66, at 1612-14.

75 We are indebted to Stanley Fish for this term.

76 See Philip Bobbitt, Constitutional InTERPRETATION 8-10 (1991).

77 See Philip Bobbitt, Constitutional Fate: Theory of the Constitution 5-8 (1982); BоввIтT, supra note 76 , at 11-22. 
rhetoric is both sound and important78 The "law-talk" that lawyers, judges, politicians, and citizens employ in discussing the Constitution is structured in a set of repeatable rhetorical topoi (topics for argument), such as text, structure, intentions, consequences, natural justice, and so on. 99 These topoi provide the common basis through which Americans talk and reason about the Constitution. A large part of learning the law is acquiring the ability to memorize, recognize, and master these topoi, and making their use in argument and discussion second nature. The canon of permissible constitutional topoi - a canon that alters over time - is one of the central determinants of our constitutional culture.

2. Canonical Problems and Approaches. - A second variety of deep canonicity consists of the approaches and questions that a culture or a discipline employs or asks itself. These approaches and questions include the kinds of issues that the culture or discipline finds interesting, as opposed to those that it views as tedious or irrelevant. They also include those ideas so basic that they do not even appear on the "radar screen" of the imagination. This canon includes both what is overtly problematized and what is thought so obviously important that its articulation is not even necessary to the members of the culture. We call this the "canon of problems and approaches." Just as Thomas Kuhn pointed out that certain generations of scientists share common "paradigms" of research, 80 so too members of a culture or discipline may have their own distinctive problematics and methods of framing and solving problems.

The canon of problems and approaches is as characteristic of any academic discipline as its purported subject matter. Different groups of academics - for example, rational choice political scientists and cultural anthropologists - often have very different ways of approaching a question and often find very different things important in a particular situation. Indeed, they may tend to characterize the situation in quite disparate and even contradictory ways. To the extent that law is an academic discipline, it too has its characteristic ways of formulating and approaching questions. Pierre Schlag has repeatedly tried to show, for example, that legal academics routinely frame matters in terms of what Schlag calls "normative legal thought.' 81 In other words, for legal academics, the point of analysis is to develop norms that might be followed by some court or some legislature, or to offer methods for deciding cases correctly. Even when legal academics eschew specific policy reforms, Schlag insists, they still speak in terms of advancing

\footnotetext{
78 See Balkin \& Levinson, supra note 27 , at $1774-78$.

79 On the topical approach to legal interpretation generally, see THEODORE VIEHWEG, TOPICS AND Law: A Contribution to Basic Research In LaW (W. Cole Durham, Jr. trans., 1993) and J.M. Balkin, A Night in the Topics: The Reason of Legal Rhetoric and the Rhetoric of Legal Reason, in LaW's Stories: Narrative And Rhetoric In The Law 211-24 (Peter Brooks \& Paul Gewirtz eds., 1996).

80 See Thomas S. Kuhn, The Structure of Scientific Revolutions 43 (2d ed. 1970).

81 Pierre Schlag, Normativity and the Politics of Form, 139 U. PA. L. Rev. 801, 808 (1991).
} 
particular normative political positions, a rhetorical style that is very similar to and indeed is ultimately derived from their legal habits of debating rules and policies. 82

Thus, Schlag points out, American legal academics routinely attempt to turn the teaching of other disciplines into knowledge that can be used in a doctrinal test or offered as authority for a legal argument before a judge or legislature 83 Because other disciplines do not research questions or produce information with these goals in mind, normative legal thought inevitably reshapes and (in Schlag's view) domesticates their work. 84 Yet as long as legal academics are shaped by their canonical approaches indeed, as long as the academic practice of law is constituted by these approaches - legal academics will continue to imagine, pose, and answer questions in precisely this way. The assumptions of normative legal thought are so central to the work of legal academics that they are usually not even discussed; they literally go without saying.

3. Canonical Narratives. - An equally important and pervasive part of the rhetorical canon are "canonical narratives." Every society has a set of stock stories about itself, which are constantly retold and eventually take on a mythic status. 85 These stories explain to the members of that society who they are and what values they hold most dear. These stock stories are both descriptive and prescriptive: they not only frame our sense of what has happened and how events will unfold in the future, but also explain how those events should unfold 86

Constitutional interpretation is full of such stock stories. There are stock stories about Americans as courageous pioneers who won the West, stories about America as a nation of immigrants who came to these shores in search of liberty and equal opportunity, and stories about America as a distinctive country that has always existed free from those forms of feudalism and social hierarchy characteristic of the Old World or has self-

82 See Pierre Schlag, Normative and Nowhere To Go, 43 StAN. L. REv. 167, 177-80, 184-85 (1990); Schlag, supra note 81, at 808-10. The canonical approach is evident in the typical "job-talk" in which aspirants seeking positions in the legal academy routinely feel it necessary to offer proposals for legal reform that correct some deficiency identified in the main body of the talk. Few candidates dare to eliminate such a normative prescription, much less assert the irrelevance of normativity to successful legal scholarship. (Perhaps for the same reason, even fewer are willing to acknowledge the more modest position that they do not yet have sufficient education or experience to presume to offer solutions to significant problems of law or society.)

83 See Pierre Schlag, Clerks in the Maze, 91 Мich. L. Rev. 2053, 2059-60 (1993).

84 See id. at 2060.

85 For a discussion of "stock stories" in law, see Gerald P. López, Lay Lawyering, 32 UCLA L. REv. 1, 5-9 (1984).

86 On the role of narrative constructions in shaping belief, see J.M. BALKIN, CULTURAL SOFTwARE: A THEORY OF IDEOLOGY (forthcoming 1998) (manuscript at ch. 9, on file with authors); JEROME Bruner, Acts of Meaning 35-36 (1990); L.H. LaRue, Constitutional Law as Fiction: NarRative in the Rhetoric of Authority (1995); and Richard Slotkin, Gunfighter Nation: The Myth of the Frontier in Twentieth-Century America 10-21 (1992). 
consciously thrown them off 87 These stories, and others like them, are as central to constitutional interpretation as the opinions of any jurist. Indeed, they are so familiar that we often do not recognize the many ways they are invoked to frame and justify legal arguments.

Take, for example, that most canonical of constitutional cases, McCulloch v. Maryland. In McCulloch we find Chief Justice John Marshall justifying an expansive conception of federal power not merely through textual and structural interpretation, but also by telling a story about what America was and what it would become. "Throughout this vast republic, from the St. Croix to the Gulph of Mexico, from the Atlantic to the Pacific," Marshall argued, "revenue is to be collected and expended, armies are to be marched and supported.... Is that construction of the constitution to be preferred which would render these operations difficult, hazardous, and expensive?" 88 It is particularly telling that Marshall chooses to ascribe borders to the United States much larger than those actually existing in 1819, when McCulloch was written. In Marshall's narrative - one that would be retold countless times under the more familiar name of "Manifest Destiny" - the United States was to become a great country, not only in spirit but also in resources and size; and great countries need constitutions that give them the flexibility to grow and attain their promised greatness.

As Lewis Henry LaRue has pointed out, it is this familiar narrative of America's destiny, as much as anything else, that underpins and justifies the expansive constitutional interpretation of national power in McCulloch 89 The narrative is not everything, but it is surely something. If we told a different story - a Jeffersonian story of a tranquil land of agrarian farmers who hoped to avoid the corruptions of ambition and avarice characteristic of European monarchies, who sought merely to live their lives in peace and harmony in small, close-knit communities - we might well imagine that it should be "difficult, hazardous, and expensive" for the national government to gather revenues, raise armies, sweep across the Continent, and conquer all in its path. If we told a story that opposed the depravity and overreaching of grasping monarchs and their prime

87 The canonical argument for the distinctiveness of America is LOUIS HARTZ, THE LIBERAL Tradition in America: An Interpretation of American Political Thought Since the Revolution (1st ed. 1955). The locus classicus for the myth of the frontier - although expressed not as myth but as fact - is FredericK JACKSON TURNER, THE FrontIER IN AMERICAN History (1920). Richard Slotkin has reinterpreted Turner's Frontier Thesis as part of a grand series of interlocking American myths deeply embedded in American culture, including myths of "The Savage War," the "Bonanza," and "Regeneration through Violence." Richard Slotkin, The Fatal Environment: The Myth of the Frontier in the Age of Industrialization, 1800-1890, at 51-63 (1985); Slotkin, supra note 86, at 1-21; $c f$. Richard Slotkin, Regeneration Through Violence: The Mythology of the American Frontier, 1600-1860, at 563-65 (1973) (describing the myth of regeneration through violence in American history, culture, and rhetoric).

88 McCulloch v. Maryland, 17 U.S. (4 Wheat.) 316, 408 (1819).

89 See LARUE, supra note 86 , at 88-90. LaRue calls this the "story of change and growth." Id. at 90. 
ministers to the simple virtues of a self-reliant republican citizenry, we might well want to nip in the bud any potential mechanisms of national aggrandizement.

In like fashion, a stock story about Protestant dissenters fleeing religious persecution in Great Britain seems to undergird much of the law of religious freedom in this country. This stock story portrays religion as a dangerous and potentially oppressive element in civil society that fosters intolerance and social strife and therefore must be kept strictly separated from the organs of state power. According to this stock story, the more fervent a religious belief, and the more determinedly a religious movement asserts authority over its followers, the more threatening it is: fanatical or exotic forms of religious enthusiasm, on the one hand, and the hierarchy of the Catholic Church on the other, become representative examples of religion's most divisive and oppressive features. Conversely, religious expression is most welcome when it most resembles watered-down or domesticated versions of mainline Protestantism. In the past, this stock story has been used to justify oppression of Mormons and Catholics in the name of protecting American governments (even though, ironically, the persecutions that originally led to the exodus from Great Britain were conducted by fellow Protestants). In the present, the myth is invoked against evangelical Protestants, Christian conservatives, Orthodox Jews, and all manner of contemporary religions and cults 90

The stock story of the flight of the first European-Americans from religious persecution is now being contested by a new myth of pluralism and multiculturalism. Not surprisingly, this new myth helps generate very different doctrinal conclusions: because Americans are a deeply religious people with many different forms of spirituality, the state should accommodate religion and should recognize and even help foster our spiritual values. The difference between this new myth and the previous one is symbolized by the difference between the hostility expressed by Justices Black, Douglas, and Brennan toward state support of parochial schools and the relaxation of those strictures in the opinions of the contemporary Supreme Court.91

Perhaps the most basic stories used in American constitutional interpretation are stories about the progress of the American nation and its laws. Robert Gordon has observed that "American legal argument from the Founding onward consistently relied upon a core narrative of liberal progress, the story of liberal modernization, by which law both followed and facilitated the evolution of society away from feudalism, tyranny and superstition and towards increasing freedom.' 92

\footnotetext{
90 See id. at 16-31.

91 See Agostini v. Felton, 117 S. Ct. 1997, 2016-17 (1997) (overruling Aguilar v. Felton, 473 U.S. 402 (1985)); Rosenberger v. Rector of the Univ. of Va., 515 U.S. 819, 845-46 (1995).

92 Robert W. Gordon, The Struggle Over the Past, 44 Clev. St. L. Rev. 123, 129-30 (1996).
} 
Because the narrative of progress is so deeply ingrained in American culture, it is not surprising that both liberals and conservatives have employed it. The story of inevitable progress has allowed progressives to harmonize the injustices of the past with their aspirations for the future. In the progressive imagination, principles immanent at the time of the Revolution (or the founding or Reconstruction) unfold and are realized through historical struggle, emerging and working themselves pure from the parochialism and injustices of the past 93

Gordon offers Abraham Lincoln's theory of the Declaration of Independence as an example of this progressive narrative.94 Through a narrative account of the inevitable progress of American liberty, Lincoln resolved the tension inherent in a document that "declared all men to be equal even as it established a polity that legalized slavery.'95 The authors of the Declaration, Lincoln explained

did not mean to assert the obvious untruth, that all were then actually enjoying that equality, nor yet, that they were about to confer it immediately upon them. In fact they had no power to confer such a boon. They meant simply to declare the right, so that the enforcement of it might follow as fast as circumstances should permit. They meant to set up a standard maxim for free society, which should be familiar to all, and revered by all; constantly looked to, constantly labored for, and even though never perfectly attained, constantly approximated, and thereby constantly spreading and deepening its influence, and augmenting the happiness and value of life to all people of all colors everywhere. 6

Yet the narrative of progress (whether inevitable or hard-fought) can also work in a conservative direction. People can invoke comparisons between the present and the injustices of the past as proof that the country has left behind white supremacy or the denial of civil liberties, and that further reforms are unnecessary or are deviations from the path of progress. Precisely because we no longer live in the McCarthy era, precisely because of the past successes of the Civil Rights Movement and the Women's Movement, contemporary claims of deeply ingrained racism, sexism, and other remaining injustices can be discounted or dismissed as hyperbolic or, at the very least, viewed with a skeptical eye. In this way, the progressive narrative can be turned against progressive causes. As Reva Siegel has pointed out, hierarchical regimes of injustice do not vanish in the face of legal reforms but often reconfigure themselves to thrive in new legal environments 97 The happy story of progressive legal

\footnotetext{
93 See id. at $128-29$.

94 See id. at 130.

$95 \mathrm{Id}$.

96 Abraham Lincoln, The Dred Scott Decision: Speech at Springfield, Illinois (June 26, 1857), in Abraham Lincoln: A Documentary Portrait Through His Speeches and Writings 88, 91 (Don E. Fehrenbacher ed., 1964).

97 See Reva Siegel, Why Equal Protection No Longer Protects: The Evolving Forms of StatusEnforcing State Action, 49 STAN. L. Rev. 1111, 1113, 1119, 1129-31 (1997).
} 
reform can mask the elements of unjust status hierarchies that still remain, aided and abetted by the very rules that purported to disestablish them 98

Perhaps because of the success of conservative uses of the progressive narrative, many progressive and radical critics of American law have offered a counter-narrative of permanence, stasis, or inevitable return. This narrative is usually pessimistic: it argues that American society has been, and will always continue to be, racist or sexist, or otherwise deeply unfair. From the vantage point of the narrative of stasis, successive decisions, statutes, and reforms appear as ever new ways by which status hierarchies are preserved, the interests of the powerful confirmed, good intentions blunted, and injustices perpetuated 99

Yet narratives of permanence can also be effective tools of conservative rhetoric. People can justify the status quo by arguing that human nature remains constant, that our traditions remain essentially unchanged from their earliest days, or that, as the Supreme Court asserted in Plessy v. Ferguson, law "is powerless to eradicate racial instincts or to abolish distinctions based upon physical differences.' 100 In our own day, the word "cultural" can be substituted for the word "physical" with similar effect.

A third and very familiar kind of canonical narrative assumes change rather than stasis, but argues that the change is for the worse. Examples include narratives of a Golden Age, against which the present must seem debased and debauched, and stories about a moment when the Constitution was properly understood, a benchmark from which later courts and politicians have repeatedly strayed. These narratives urge us to recognize our failings, to confess our sins, and to return to the old ways. At first glance, these narrative constructions seem exclusively conservative in tone. Robert Bork's vivid comparisons of contemporary American culture (and contemporary constitutional jurisprudence) to Sodom and Gomorrah are only the most recent examples. 101 Yet progressives have also appealed to golden ages and called for a return to a more just and sensible past. Even

98 See Reva B. Siegel, "The Rule of Love": Wife Beating as Prerogative and Privacy, 105 YALE L.J. 2117, 2179-81 (1996); Siegel, supra note 97, at 1147-48.

99 Perhaps the most eloquent representative of this narrative form is Derrick Bell, whose heartfelt reflections on the permanence of American racism are collected in various works. See DeRRICK BELL, And We Are Not Saved: The Elusive Quest for Racial Justice (1987); Derrick Bell, Faces at the Bottom of the Well: The Permanence of Racism (1992); Derrick Bell, Race, Racism AND AMERICAN LAW (1970).

Often scholars on the left attempt to complicate matters by yoking the narrative of permanence with the narrative of progress. Although racism and sexism are persistent and pervasive, they have been weakened over time; nevertheless, we must be ever vigilant to their continuing presence in our lives and to their potential resurgence. Reva Siegel's argument that unjust status hierarchies achieve "preservation-through-transformation" modifies the narrative of permanence by emphasizing the dynamic features of social hierarchies and by admitting significant elements of progress, but this story nevertheless retains deep ambivalence about the prospects for reform. Siegel, supra note 98, at 2180; Siegel, supra note 97, at 1113.

100 Plessy v. Ferguson, 163 U.S. 537, 551 (1896).

101 See Robert H. Bork, Slouching Towards Gomorrah: Modern Liberalism and American DeCline (1996). 
revolutionaries find it useful to call for restoration of an invented tradition. A good example is the story of the Commerce Clause as told by supporters of the New Deal. According to this story, the Supreme Court's narrow, formalist theory of federal regulatory power during the pre-New Deal era was an abandonment of the sensible, pragmatic approach of John Marshall and the founding generation.102 Hence, the New Deal conception of a broad-ranging, flexible commerce power was not a judicial deformation of the Constitution, but rather a return to a correct understanding of the relation between federal and state power 103

4. Canonical Examples. - The final form of deep canonicity works on a somewhat different level from the others. It concerns the kinds of examples that legal academics, lawyers, judges, and students of the law take as characteristic of a particular category or problem. We call this phenomenon the selection of "canonical examples."

Cognitive psychologists from Eleanor Rosch onward have noted that human beings tend to focus on certain members of categories that they regard as most representative or salient. Rosch called these examples "prototypes."104 Prototypes are synecdoches for categories, synecdoche being the classical trope in which the part is taken to represent the whole. They are the canonical examples by which and through which individuals reason about categories, and hence they are the examples through which a great deal of human reasoning occurs. Rosch found that individuals tend to remember prototypes more easily than nonprototypical examples and that they are more likely to use them in drawing inferences about other members of a category.105 Rosch collectively called these various psychological habits of mind "prototype effects."106

102 The canonical example of this story is Robert L. Stern, The Commerce Clause and the National Economy, 1933-1946, 59 HARV. L. REV. 645 (1946).

103 Bruce Ackerman's theory of constitutional moments is a story of punctuated moments of popular self-definition and self-discovery (if not progress); it views the New Deal narrative of return as one of dissimulation. See 1 Bruce Ackerman, We the People: Foundations 159-62 (1991) [hereinafter Ackerman, Foundations]; 2 Bruce Ackerman, We the People: Transformations (forthcoming 1998) [hereinafter ACKERMAN, TRANSFORMATIONS]. For Ackerman, the Lochner-era Court was more likely the true heir of the original understanding. See Ackerman, Foundations, supra, at 153-56. However, it is important to recognize that Ackerman's generous interpretation of the Lochner era is crucial to his own narrative: it helps establish the necessary break with the past (and the tinges of illegality) that Ackerman believes are characteristic of constitutional moments.

104 See Eleanor Rosch, Cognitive Reference Points, 7 Cognitive Psychol. 532, 544-46 (1975); Eleanor Rosch, Cognitive Representations of Semantic Categories, 104 J. EXPERIMENTAL PSYCHOL. GEN. 192, 193-94 (1975); Eleanor Rosch, Principles of Categorization, in CogNITION AND CATEgorization 36 (Eleanor Rosch \& Barbara B. Lloyd eds., 1978) [hereinafter Rosch, Principles of Categorization]; Eleanor Rosch \& Carolyn B. Mervis, Family Resemblances: Studies in the Internal Structure of Categories, 7 Cognitive Psychol. 573, 574 (1975).

105 See George Lakoff, Women, Fire, and Dangerous Things: What Categories Reveal ABOUT THE Mind 40-43 (1987) (summarizing the phases of Rosch's experimental work).

106 Rosch, Principles of Categorization, supra note 104, at 37; see also LAKOFF, supra note 105, at 40-45 (describing Rosch's contributions to cognitive theory). 
One of the most important ways to understand legal culture is to study the canonical examples that members of the culture routinely call upon to formulate problems and discuss issues. Situations, categories, factual hypotheticals, and even problems themselves can be the canonical examples around which legal academics and other legal thinkers naturally tend to focus and organize their thought 107

Accordingly, we offer two examples of what we mean by canonical examples in legal thought (although we are unsure that our examples of canonical examples are themselves canonical examples of canonical examples). First, we believe that certain subjects are canonical in discussions of legal theory. When jurisprudence scholars talk about how legal reasoning works, they often draw their canonical examples from common law subjects, and even more often from constitutional law. These subjects are probably canonical because of their centrality to the culture of the first year of legal education and because many American academics who teach legal theory also teach some form of constitutional law. Indeed, the fact that we draw on constitutional law for so many of our examples in this Commentary is simply further evidence of constitutional law's hold on many people interested in legal theory. Common law subjects and constitutional law have become, for good or ill, the canonical examples of law for American legal theorists. Elsewhere we have noted that a majority of the most frequently cited articles of all time are about constitutional law subjects, even though there are many subjects of equal or greater importance to government policymakers and to the practicing bar.108 Every year the Harvard Law Review begins its initial issue with a Foreword by a noted scholar on the previous year's Supreme Court Term. These much heralded essays are almost never about antitrust, Social Security, or the regulatory problems of the Federal Deposit and Insurance Corporation. They are almost always about constitutional law, even in years when a significant majority of the Supreme Court's work involves nonconstitutional cases. These Forewords symbolize the hegemony of constitutional law in the imagination of both the academics who read and write them and the students who edit them.

Nevertheless, when making arguments about how lawyers reason, or how pervasive legal indeterminacy is, or even about the nature of legal obligation, using examples based on constitutional law may be very misleading. The problems of law are not always the problems of constitutional law. The Uniform Commercial Code, the Federal Communications Act, or the Texas Rules of Civil Procedure might prove to

107 Cf. Jed Rubenfeld, Reading the Constitution as Spoken, 104 YAle L.J. 1119, 1122 (1995) (offering a normative theory of constitutional interpretation based on the application of "paradigm cases"); Steven L. Winter, Transcendental Nonsense, Metaphoric Reasoning, and the Cognitive Stakes for Law, 137 U. PA. L. REv. 1105, 1107 (1989) (emphasizing the importance of cognitive modeling to legal thought).

108 See Balkin \& Levinson, supra note 55, at 854. 
be much better examples. Obviously, before other audiences, and for other purposes, any or all of these statutes might provide canonical examples. But that is simply further evidence of the role that prototypical examples play in structuring thought. When we say that constitutional law tends to provide canonical examples for legal theorists, we are not claiming that this tendency is a good thing. We are simply adverting to what many professors of commercial and corporate law have recognized for years: legal theorists seem to be overly concerned with constitutional law even though the vast majority of the sources of the law - and the problems that need addressing in the law - lie elsewhere.

This same canonical field provides us, not surprisingly, with our second example. Because of America's sorry history of slavery and racism, African-Americans have become the canonical example of a disadvantaged or oppressed minority, the canonical example of a social group deserving of legal protection, and indeed, the canonical example of a racial group. The Reconstruction Amendments were written largely with blacks in mind, and African-Americans were surely Justice Stone's canonical example of a "discrete and insular minority.' 109 As social movements gradually have sought to obtain equality for other disadvantaged groups - including women, Hispanic-Americans, Asian-Americans, the disabled, and most recently, homosexuals - analogies have routinely been drawn to the problem of discrimination against African-Americans. African-Americans, in short, are the canonical example for thinking about issues of equality in the United States. Yet racial and gender discrimination differ in important ways. 110 One can make a similar point about discrimination against gays and the disabled. Even within the class of ethnic minorities, HispanicAmericans and Asian-Americans face different problems than do AfricanAmericans. 111

109 United States v. Carolene Prods. Co., 304 U.S. 144, 153 n.4 (1938).

110 The canonical discussion of the differences between racial and gender discrimination is Richard A. Wasserstrom, Racism, Sexism, and Preferential Treatment: An Approach to the Topics, 24 UCLA L. Rev. 581 (1977). Cf. Sylvia A. Law, Rethinking Sex and the Constitution, 132 U. PA. L. Rev. 955, 965 (1984) (noting that arguments about categorical physical differences can be more plausibly invoked in gender cases than in race cases because of women's reproductive capacity). Obviously, women do not fit the canonical definition of a "discrete and insular minority" because, among other things, they constitute a majority of the population. See John Hart Ely, Democracy and Distrust 164-70 (1980).

These arguments about the differences between gender and racial discrimination were made before the wider acceptance of antisubordination rationales for equal protection. From the latter perspective, one might point out that women and blacks can be subordinated in very different ways. Moreover, their different forms of subordination complicate one another in the case of women of color. See Kimberle Crenshaw, Demarginalizing the Intersection of Race and Sex: A Black Feminist Critique of Antidiscrimination Doctrine, Feminist Theory and Antiracist Politics, 1989 U. CHI. LegAL F. 139-40; Angela P. Harris, Race and Essentialism in Feminist Legal Theory, 42 StAN. L. Rev. 581, 586-90 (1990).

111 See Ronald Takaki, Strangers from a Different Shore: A History of Asian Americans 474-84 (1989); Richard Delgado, Rodrigo's Fifteenth Chronicle: Racial Mixture, LatinoCritical Scholarship, and the Black-White Binary, 75 Tex. L. Rev. 1181, 1197 (1997); Jerry Kang, 
The use of African-Americans as the canonical example of a racial group in legal thought has many other interesting and important effects. It tends to make discussions about race relations bipolar, even as America's multicultural and multiracial status is becoming increasingly obvious. Equally important, viewing African-Americans as the canonical example of a racial group tends to make white racial identity invisible. Seeing blacks as the most representative example of a race tends to make whites seem like a much less good example, and it reinforces the idea that to have a race is to be more like a black person and less like a white person.

Once we recognize this form of canonicity, we discover that American legal culture is full of canonical examples. Consider the use of disputes between farmers and ranchers to explain the workings of the Coase theorem, the use of automobile accidents to discuss the operation of tort law, and the use of the requirement that the President be thirty-five years old to illustrate an "easy case" that symbolizes the determinacy of legal texts. Each era also has its canonical examples of judicial activism that affect its views about the role of the judiciary: Lochner v. New York 112 in one era, Brown v. Board of Education in another, Roe v. Wade ${ }^{113}$ in still another.

Examples of canonical examples could be multiplied, but two points are important for our purposes. First, the selection of canonical examples often operates in the background rather than as a conscious choice; that is precisely why these examples are forms of deep canonicity. Second, the use of canonical examples often has important ideological effects effects that may be just as powerful and just as important as the choice of which cases and materials to study in the canonical first-year course.

\section{E. Prescriptive and Sociological Approaches}

The idea of deep canonicity suggests that much of canon formation occurs beyond the conscious apprehension of the members of a culture or discipline. Much of what is canonical is not the result of conscious planning but of the serendipitous development of the ever-shifting contours of a culture, a discipline, or an interpretive community. To be sure, individuals and groups may fight vigorously over what is canonical, but what emerges may be very different from what they desire. To paraphrase Marx, individuals and groups construct canons, but not as they intend. Moreover, the contending sides may already agree on things that are so

Negative Action Against Asian Americans: The Internal Instability of Dworkin's Defense of Affirmative Action, 31 HaRV. C.R.-C.L. L. Rev. 1, 20 (1996); Deborah Ramirez, Multicultural Empowerment: It's Not Just Black and White Anymore, 47 Stan. L. Rev. 957, 959-60 (1995); Frank H. Wu, Changing America: Three Arguments About Asian Americans and the Law, 45 AM. U. L. REv. 811, 812 (1996); Frank H. Wu, Neither Black Nor White: Asian Americans and Affirmative Action, 15 B.C. THIRD WORLd L.J. 225, 281-84 (1995); Note, Racial Violence Against Asian Americans, 106 HARV. L. Rev. 1926, 1930-33 (1993).

112198 U.S. 45 (1905).

113410 U.S. 113 (1973). 
taken for granted, and thus already so canonical to their thought, that the idea of contesting them does not even arise. Ultimately, canons and the canonical are collective enterprises involving both the conscious and unconscious elements of a culture. They are historical creations in which rational design and precision engineering are wishful thinking.

Initially we described the question of canonicity in prescriptive terms: we asked what cases and materials should be included in a particular version of the canon, whether pedagogical, cultural literacy, or theoretical. Of course, the notion of what ought to be canonical presupposes the possibility of shaping the canon nearer to our hearts' desire. However, we can also approach the question of canonicity sociologically. We can ask how a particular interpretive community actually forms its canon and why. In the latter case, we are especially interested in why people converge or diverge in their sense of what is canonical and in how and why their judgments change over time.

The sociological study of the canon - what social forces explain the creation of a given set of canonical materials - and the prescriptive study of the canon - what materials one ought to read or assign to others can intersect. Once we understand how a canon gets constructed, we may be able to offer an ideological critique of its substance and the processes by which it is formed. For example, we may discover that a particular construction of a canon gives short shrift to certain types of questions (for example, how chattel slavery was integrated into every aspect of American law ${ }^{114}$ and that, as a result, this construction gives a particular normative slant to what people consider the important questions facing anyone in the business of thinking about law. ${ }^{115}$ If one believes that setting agendas and framing questions significantly affect how these questions are answered, then a sociological approach to canon formation may have considerable normative importance for the study of law.

Indeed, a sociological approach leads us to a more fundamental question about canonicity than the particular contents of various canons: why should debates about the canons of law arise at this particular time in the history of the legal academy? Debates about the canon arise when what is canonical is no longer taken for granted, no longer "goes without saying," but becomes controversial in some significant way. As noted above, debates may also occur when an imagined unity of thought and practice seems to be breaking down. They may occur when the forces of cultural reproduction that ensure the replication of interpretive assumptions in successive generations of a discipline's membership no longer operate as smoothly as they once seemed. When a previous generation cannot reproduce a relative uniformity of interpretive assumptions in a new

\footnotetext{
114 The general answer is all too easily. See the magisterial analysis in ThOMAs D. MorRIS, SOUTHERN SLAVERY AND THE LAW, 1619-1860, at 61-65 (1996).

115 For a discussion of this point, see Sanford Levinson, Slavery in the Canon of Constitutional Law, 68 Chi.-Kent L. Rev. 1087, 1087 (1993).
} 
generation - whether due to changes in demographics, to recalcitrant experience, or to economic factors - a crisis of confidence emerges that manifests itself in debates about the purposes of the common enterprise. One way in which this crisis surfaces is in controversies about what is canonical. These controversies occur repeatedly throughout the history of any discipline. Now it is the turn of the legal academy to be seasoned by its own discontents.

One clue to the source of concern about the canon, therefore, is demographic changes in the composition of the legal academy and corresponding changes in the makeup and practices of the organized bar. An increasingly "diverse" academy will almost certainly generate diverse notions about what is most worth teaching, studying, and discussing. Indeed, the same phenomenon has occurred in American liberal arts colleges, as a more varied group of people has gained entry into the academy in the past generation, producing predictable struggles over the canon in humanities departments. In like fashion, because of changes in demographics, economics, and politics, members of the legal academy may begin to ask themselves whether casebooks should include materials from "new" or "different" perspectives - for example, citations to the feminist and critical race theory literature, excerpts from novels and plays, increased coverage of slavery, and so forth.

A second possible source of concern over the legal canon is the emergence of interdisciplinary scholarship. The entry of other disciplines into the study of law threatens to change the pedagogical canon, the cultural literacy canon, and the academic theory canon at a single stroke. At some point hermeneutics, public choice theory, and feminist theory threaten to become as important to the legal academy as the dormant commerce clause or the doctrinal refinements of promissory estoppel. (Perhaps this point has already been reached.) Of course, the rise of interdisciplinary study may not be so much the cause of present-day concern with the canon as a symptom of more general social and institutional changes that, in turn, have given rise to questions about canonicity. In any case, when a distinguished jurist and former academic writes a volume on jurisprudence entitled Overcoming Law, ${ }^{116}$ one might guess that traditional views of what is canonical to legal study are in for stormy weather.

A third reason for increasing interest in the composition of the constitutional canon in particular has to do with the perceived threat to the beloved precedents of the beloved Warren Court, which seem daily under assault by current members of the U.S. Supreme Court. Posed in this light, the question of the constitutional canon appears to concern whether cases like Miranda v. Arizond ${ }^{117}$ and Brown v. Board of Education are

116 Richard A. Posner, Overcoming LaW (1995).

117384 U.S. 436 (1966). 
sacred cows that cannot be touched or whether they are revisable like everything else. A constitutional canon becomes a means of ensuring their continued vitality. For example, Cass Sunstein, a well-known liberal constitutional theorist, has insisted that "an approach to constitutional interpretation is unacceptable if it entails the incorrectness of Brown v. Board of Education." 118 This is more than a claim that Brown must be taught to law students; after all, that is also the case with Lochner v. New York. Rather, Sunstein is arguing that Brown is normatively canonical. One can no more criticize it than one can suggest that Mozart is a wildly overrated composer of music for eighteenth-century dinner parties. One establishes oneself as a cultured person by affirming Mozart's genius; one establishes oneself as a properly acculturated lawyer by affirming Brown's correctness.

Note that in this debate about canonicity it is liberals who defend the academic theory canon against the "barbarians" on the right. There is a certain irony here. Clinging to these Warren Court and early Burger Court cases as canonical is "foundationalist" in a sense that left-liberals in the current academy might loudly disdain if the issue were posed in epistemological terms. In studying the constitutional canon sociologically, therefore, we might consider the curious relationship between the antifoundationalist pragmatist who asserts that all knowledge is revisable if good enough reasons can be provided and the constitutional theorist who demands that any theory of constitutional law must explain and justify Roe v. Wade, while showing why Bowers v. Hardwick 119 is wrongly decided. There is just something unavoidably foundationalist about canons and the canonical, which we take to include all claims of the form: "an approach to constitutional interpretation is unacceptable if it entails the incorrectness of $X . " \quad$ The idea of a truly antifoundationalist canon, if not an oxymoron, must at least create a perpetual state of intellectual tension 120

\section{F. Institutional Contexts and Strange Bedfellows}

Liberal attempts to canonize liberal precedents remind us that we must understand debates about the canon in their institutional context. Indeed, institutional factors help produce some of the most significant differences between literary and legal debates over the canon. Both debates involve a struggle for authority, but the terms of the struggle are different in each case because the institutional context differs. Differences in the political meaning of the attack on the canon stem in large part from differences in

118 Cass R. Sunstein, In Defense of Liberal Education, 43 J. LEGAL Educ. 22, 26 (1993).

119478 U.S. 186 (1986).

120 Obviously, these prescriptive debates about the academic theory canon may have consequences for the construction of the pedagogical canon as well. For example, depending upon our bedrock commitments, we might focus on either Miranda or the writings of the antifederalists. This is one of many ways in which the construction of the academic theory canon affects the content of the pedagogical canon and the cultural literacy canon. 
how authority is created in law and liberal arts and in who has control over the respective canons.

In liberal arts departments, traditional canons are being attacked primarily from the left side of the political spectrum. However, the pedagogical and academic theory canons in constitutional law are contested from both the left and the right. It is hardly surprising that critical race theory and feminism might wish to challenge parts of the pedagogical canon in ways reminiscent of the debates waged in liberal arts departments. Less analogous is the attack on the theoretical canon - the set of correctly decided cases that any serious theory of constitutional law must explain - from the political right. Here we find left-liberals defending a normative canon that includes cases like Roe v. Wade against assaults by the political right, led and symbolized by the right wing of the Supreme Court and the Reagan-Bush judiciary.

This two-front war in law can produce some interesting role reversals. When the liberal constitutional scholar Cass Sunstein declared the lasting correctness of Brown v. Board of Education, he was playing a role not unlike that of cultural conservatives Donald Kagan and E.D. Hirsch, who have tried to preserve the Western canon of great books from the onslaughts of multiculturalism and deconstruction 121 In similar fashion one could imagine liberal scholars defending Roe or Regents of the University of California v. Bakke122 against the likes of Antonin Scalia or William Rehnquist. Yet Sunstein's defense of the canon was directed not at some conservative jurisprude hoping to wreak havoc with liberal precedents; it was aimed at a still more leftwing scholar — Stanley Fish 123 Politics makes strange bedfellows, but the ones canons make may be stranger still.

This curious state of affairs is due in large part to the institutional differences between legal and liberal arts education, and in particular, differences in the ways in which authority is created and defended in the legal and liberal arts academies. We noted previously that the attack on the liberal arts canon has come primarily from "the left." However, this expression conflates many different strands of thought. Let us separate out two of them. The first tendency, which might be termed the "political left," promotes radical egalitarianism on issues of race, class, gender, and sexual orientation. The second tendency, which we might call the "methodological left," is an epistemological and methodological attack on all received forms of canonicity and objectivity; it can take the form of antifoundationalism, poststructuralism, postmodernism, the study of culture as a form of power/knowledge, and so on 124 Whether this stance is truly

121 See Sunstein, supra note 118 , at 26.

122438 U.S. 265 (1978).

123 See Sunstein, supra note 118 , at 22

124 For a critical perspective on these trends in legal scholarship, see Suzanna Sherry, The Canon in Constitutional Law 3-12, 26-29 (Apr. 1997) (unpublished manuscript, on file with authors). 
culturally relativist, it is often so portrayed by its opponents. Now one can be methodologically "on the left" without being politically on the left, and vice versa, but in today's liberal arts academy the two tendencies seem to travel together. Conversely, attacks on the methodological left and commitment to the canon seem to be identified with, if not political conservatism, at least the forces of political moderation. (Nevertheless, in the hothouse of the contemporary liberal arts academy, one can be quite liberal and still find one's self on the starboard side of these debates.)

As a result, contemporary attacks on the liberal arts canon from "the left" often serve both a particular political agenda and a methodological agenda, which, in the present context, seems to serve that political agenda. 125 Nevertheless, one of the most important features of alliances - including intellectual alliances — is that they are never permanent and acontextual, but take their strength from the institutional and political contexts in which they occur. If one changes that context ever so slightly, one sometimes finds stunning shifts, and hence, strange bedfellows.

So it is with the legal academy, at least when viewed from the standpoint of the liberal arts academy. The left-liberal who wishes to defend the canonical status of the Warren Court's liberal precedents must fend off attacks from the political right and the methodological left, but not necessarily from the political left. Critical race scholars — who are presumably even further to the political left than Professors Sunstein or Fish - would also regard the defense of Brown v. Board of Education as a sine qua non of any serious constitutional theory. They might claim that Brown stands for something quite different than Antonin Scalia believes it stands for, but that goes to its meaning and not to its canonical status.

Professor Fish, by contrast, has been playing an altogether different game. In suggesting that all canons can be historicized, ${ }^{126}$ Fish has simply adverted to the inherent tension between currently fashionable methodologies and Warren Court Fundamentalism. Scratch a liberal pragmatist, Fish seems to say, and you will find a Warren Court Fundamentalist. Even though many of the younger generation of scholars recognize (and loudly pronounce) that the Warren Court is dead and gone, they still want to preserve large parts of the Warren Court canon.

But is the preservation of this canon really in the hands of law faculties? This brings us to our second point about the importance of institutional context. Differences in the debates over the canon in legal and liberal arts faculties stem from differences in control of authority in

125 But see J.M. Balkin, Transcendental Deconstruction, Transcendent Justice, 92 MicH. L. REV. $1131,1138,1149-57,1159-62,1174-76$ (1994) (arguing that this connection is overstated because progressive political uses of deconstruction can be flipped to serve a very different politics).

126 See Stanley Fish, Not of an Age, But for All Time: Canons and Postmodernism, 43 J. LEGAL EDUC. 11, 20 (1993) (noting that "the insight that canons are socially constructed, rather than undermining their claims, merely directs us to the history in the course of which those claims have been established"). 
law and the liberal arts. Liberal arts scholars have more control over the academic theory canon of their discipline than do legal academics. They teach the courses, assign the books, and become the arbiters of quality and taste in intellectual production and in significant parts of "high culture." Thus, for example, what gets studied in history departments and what is considered good or bad history is, not surprisingly, largely defined by what historians want to teach, what they think is worth studying, and what history they think is well done and well-written. Of course, because liberal arts scholars do not have control over popular culture, they do not fully control what is canonical in their disciplines; yet they have considerable authority nevertheless.

In contrast, constitutional law professors have much less control over the content of the academic theory canon of their discipline. This canon is largely shaped and controlled by forces beyond their direct control - the courts and the political branches. Law professors exercise their control primarily through influence over their students and their fellow academics and through their work as legal advisors and advocates. This influence is not insignificant: much of this Commentary is devoted to showing that the way in which constitutional law is taught may affect the development of constitutional doctrine. Nevertheless, the power of law professors over the academic theory canon of constitutional law pales in comparison to the control that historians have over the question of what is considered good history or a proper subject of historical study.

Thus, left-liberal constitutional theorists are defenders of an academic theory canon over which they have comparatively little control. When the political forces that surround them demand a reassessment of liberal precedents, they are forced into a jurisprudential posture that celebrates stare decisis and the rule of law - in short, one that celebrates the canonical nature of these precedents. Not so for the left-wing liberal arts professor: the power to change the pedagogical, cultural literacy, and academic theory canons of her discipline is largely within her own control. She may take the offensive, knowing that to carry the day is simultaneously to win control of the canon-making apparatus. Liberal legal academics in a conservative age, on the other hand, must continually fight a rearguard action until like-minded judges ascend to the bench. Even at that point, they do not gain control of the academic theory canon, but once again find themselves largely as cheerleaders for what has now become the winning team. In any case, during the most urgent moments of their struggle to preserve the work of the Warren Court and its timeless precedents, probably the last thing they feel they need is some joker from the English department pointing out that the whole thing is socially constructed. Thus, in comparing the institutional differences between law and the liberal arts, we might note that canons are most likely to make the strangest bedfellows when one has the least choice about where one spends the night. 


\section{Constitutional Canons and Constitutional Thought}

Fights about the canon in literature assume for the most part that there is some connection between the materials that constitute a canon and how individuals think. The materials that students and educators most frequently encounter set the agenda for problems - they establish what is normal and what is deviant, what is expected and what is out of the ordinary, and what are good and bad examples of practice. However, as we have noted, in a deeper sense what are most canonical are habits of thought. These habits of thought lead to the selection and retention of those materials that are called canonical. Exposure to those materials, in turn, helps reproduce and reinforce the habits of mind that shape what materials are deemed canonical. Thus, it is false to say that canonical materials by themselves shape thought, for they may simply reflect the kind of thought that leads to their continued selection. Because canonical materials are both causes and effects of thought, the causal story of how canons influence us is inevitably a complicated one.

When we speak of a canon, we are really speaking of a process of reproduction - a reproduction of the tools of understanding, the "cultural software" that people use to formulate problems, to understand the world, and to understand their own actions 127 From this perspective, what makes canons canonical is precisely that they do reproduce themselves in successive generations of human minds. The establishment of a canon leads to an accentuated focus on some materials as opposed to others. Because space and attention in human minds are limited, frequent transmission of canonical works helps draw greater attention to them and thus helps ensure their perpetuation and proliferation. Indeed, the effect is even more profound. By capturing more and more of the limited space in human minds and imaginations, canonical materials begin to define the very nature of what is worth talking or thinking about. They have a bootstrapping effect that helps ensure their continued centrality as well as their future reproductive success 128 Thus, things do not become canonical simply because they are important; often they become important because they are canonical.

\section{A. Comparativism and Court-Centeredness}

We have identified the pedagogical or teaching canon in constitutional law as those cases and materials (historical examples, legislative history, speeches by legislators and presidents, etc.) that are regularly taught and read in constitutional law courses, or that should be regularly taught and read in those courses. Any inquiry into the pedagogical canon must be concerned not only with content, but also with form. It must be concerned

127 BALKIN, supra note 86, at 3-4, 25.

128 We have made a similar claim about citations to legal scholarship, which also tend to create a set of canonical materials. See Balkin \& Levinson, supra note 55, at 845. 
not only with the issues that are taught but also with the kinds of materials that are used to teach them, whether they be cases, statutes, academic arguments, or factual studies. This latter question of form is likely to be overlooked. The question is not what Supreme Court cases should be taught, but rather whether what should be taught are Supreme Court cases rather than Lincoln's first inaugural address or James Madison's speech about the constitutionality of the Bank of the United States.

Here sociological questions merge with prescriptive ones. One reason why the constitutional canon is almost exclusively constructed in terms of U.S. Supreme Court cases is the general court-centeredness of legal education. Indeed, it is more than court-centeredness - it is U.S. Supreme Court-centeredness. Although much important constitutional law is decided in circuit and district courts, ${ }^{129}$ constitutional law casebooks tend to emphasize only the Supreme Court's decisions.

Juxtaposing Supreme Court opinions with the interpretations of such distinguished statesmen as James Madison, Wendell Phillips, Frederick Douglass, and Abraham Lincoln, casts a very different light on the Supreme Court's purported role as the sole authoritative interpreter of the meaning of the Constitution. The U.S. Supreme Court-centeredness of the pedagogical canon in constitutional law has important ideological effects. It tends to reinforce the Supreme Court's finality in matters of constitutional interpretation. Conversely, it tends to downplay the possibility (and desirability) of "protestant" interpretations of the Constitution, which view each citizen as having the duty to interpret the Constitution for herself.

Moreover, the Supreme Court-centeredness of the constitutional canon means that law students quite literally never consider, in any systematic way, those aspects of the Constitution that never become the subject of litigation, such as fixed periods between elections, bicameralism, the twoterm limit for presidents, or the remarkable hurdles facing anyone who wishes to engage in formal constitutional amendment under Article V. These structural features of the Constitution are at least as important as the dormant commerce clause or the First Amendment protections accorded to commercial speech, but they almost never become part of the law student's consciousness.

That might not be such a problem if legal pedagogy were only concerned with preparing students for legal practice. Almost no practicing lawyer will ever be called upon to address, in a litigated case, whether it is really defensible that Vermont has the same number of senators as Texas. (Of course, most law students will also rarely litigate cases involving the

129 See, e.g., Action for Children's Television v. FCC, 58 F.3d 654, 659-70 (D.C. Cir. 1995) (en banc) (upholding the constitutionality of a statute prohibiting indecent broadcast programming between 6 a.m. and 10 p.m.); Mozert v. Hawkins County Bd. of Educ., 827 F.2d 1058, $1063-70$ (6th Cir. 1987) (rejecting a Free Exercise Clause claim by fundamentalist Christian parents who sought to avoid exposing their children to secular materials). 
dormant commerce clause or the First Amendment.) However, many law professors believe that it is their function to train lawyer-citizens as well as legal practitioners, especially because the United States continues to draw an excessive number of its leaders from the ranks of professionally trained lawyers. We must recognize that, by neglecting these important structural features of the Constitution, we are inflicting on the nation graduates whose ignorance of fundamental structural issues leaves them ill-equipped to discuss many vital issues of governance. Trained in law schools to have entirely too much faith in the Constitution and never having considered some of its manifest imperfections - indeed, outright stupidities 130 — our students will have few tools with which to think about the adequacy of the institutions bequeathed to us by our long-dead founders.

Just as the pedagogical canon is innocent of these important issues, it also seems completely uninterested in comparisons with the constitutions of other lands and times. Extraordinarily few casebooks in any subject include material from foreign legal systems. This absence is particularly glaring in constitutional law courses. Of course, if one wants comparativism, one need hardly go past our own shores. The first comparisons might be made to other domestic constitutions, including the discarded Articles of Confederation, the fifty state constitutions that complement the United States Constitution, ${ }^{131}$ and even the Constitution of the Confederate States of America, which bears many interesting differences from the antebellum Constitution. But beyond our borders, one might also look to the written constitutions of well over 100 other countries 132 the United Nations Charter, and the Treaty of Rome 133 And this list, of course, does not even include judicial opinions by constitutional courts in other countries. Through these opinions we might compare not only the treatment of particular structural or human rights issues, but also the modes of interpretation that these courts employ. Just as there is more than one way to design a democracy, there is surely more than one way to interpret a constitutional provision 134

130 See Symposium, Constitutional Stupidities, 12 Const. Commentary 139 (1995).

131 State court judges have sometimes interpreted state constitutional provisions to reach results quite different from U.S. Supreme Court decisions. For example, after the Court refused to recognize the existence of a right to equal educational resources in San Antonio Independent School District v. Rodriguez, 411 U.S. 1, 54-55 (1973), a number of state courts found such a right in their state constitutions, including Texas, the state in which Rodriguez was originally brought, see Edgewood Indep. Sch. Dist. v. Kirby, 777 S.W.2d 391, 397 (Tex. 1989) (interpreting the Texas state constitution to include a right to "substantially equal opportunity to have access to educational funds").

132 See, e.g., Constitutions of the Countries of THE World (Albert P. Blaustein \& Gisbert H. Flanz eds., 1997).

133 See, for example, J.H.H. Weiler, The Transformation of Europe, 100 YALE L.J. 2403 (1991), a fascinating article that compares developments under the Treaty of Rome to early developments in the history of the U.S. Constitution.

134 We note, alas, that the contemporary Supreme Court seems determined to aid and abet the ignorant disregard of the constitutions of other countries. Justice Breyer's recent suggestion in Printz v. United States that the Court consider the experience of the European Union was roughly dismissed by 
Both historical and what is generally called "comparative" study (i.e., the study of other legal cultures) are really special cases of comparativism. Comparativism operates either temporally or spatially - it either takes us back in time or outward to other places. In both cases, the purpose is the same. It is to make the object of our study - in this case the United States Constitution - "strange" to us. (Literary critics are well aware of the similar technique of "defamiliarization.") We hope to see how a problem dealt with in one way might be dealt with in another way, or how a particular feature of our political life looks when it is separated from concomitant features that we unthinkingly blend together.

The American legal academy's general failure to consider other constitutions and other constitutional opinions in constitutional pedagogy has two significant ideological effects. First, it tends to reinforce the idea that the U.S. Constitution is the standard case of a written constitution; hence other constitutions will be judged with respect to their similarity to or their difference from this norm. Second, it tends to make the U.S. Constitution not only a descriptive but a prescriptive norm for constitutional design. This tendency is revealed whenever American constitutional lawyers eagerly offer advice to emergent political systems struggling with the task of constitution writing. Like all too many of their professors, students rarely grapple with the possibility that there are other ways of structuring governments or dealing with the problems of democratic institutions - for example, the choice between proportional representation and "winner take all" elections, or between parliamentary models and models that feature separation of powers 135

Justice Scalia's majority opinion: "We think such comparative analysis inappropriate to the task of interpreting a constitution, though it was of course quite relevant to writing one." Printz v. United States, 117 S. Ct. 2365, 2377 n.11 (1997). Yet if the Framers themselves engaged in comparativism, one would think that a devotee of original understanding should have a similar interest, at least as an aid to divining their larger purposes. Nevertheless, Scalia insists, in a fit of nationalistic fervor, that such inquiries are completely unnecessary, for "our federalism is not Europe's." Id. at $2378 \mathrm{n} .11$. It is "the unique contribution of the Framers to political science and political theory." Id. (quoting United States v. Lopez, 514 U.S. 549, 575 (1995) (Kennedy, J., concurring) (citing Henry J. Friendly, Federalism: A Foreword, 86 YALE L.J. 1019 (1977))) (internal quotation marks omitted). That claim may or may not be true, but it seems quite irrelevant to the point of comparativism, which is better to understand ourselves through comparison with others. By contrast, what Scalia offers us is the kind of self-satisfied strutting that gives chauvinism a bad name.

135 Indeed, one of the elements most sorely missing from the current constitutional canon is a concern with facts. Rarely do constitutional law casebooks present the kinds of empirical data that would let students judge the accuracy of the Supreme Court's sometimes astonishingly cavalier pronouncements about the outside world.

Consider, for example, the "chilling effect" that liberal legal scholars fear will arise from regulation of the press. Do we have any reason to believe that the fear of libel judgments has a greater effect on press behavior than, say, the fear of retribution from a paper's leading advertiser? See Frederick Schauer, Liars, Novelists, and the Law of Defamation, 51 BRook. L. Rev. 233, 246-47 (1985); Frederick Schauer, Uncoupling Free Speech, 92 Colum. L. REv. 1321, 1329-30 (1992).

Next consider conservative paeans to the virtues of federalism. Striking down a federal scheme regulating radioactive waste, Justice O'Connor proclaimed: "State sovereignty is not just an end in itself: 'Rather, federalism secures to citizens the liberties that derive from the diffusion of sovereign 


\section{B. Practice Concerns and "Timeless Problems"}

"Legal practice" concerns exert a somewhat different influence on the pedagogical canon. Casebook authors often think it important to map the way legal doctrine is "actually" practiced. To the extent that casebooks shape the way that certain problems are thought about, this may be a selffulfilling prophecy. Nevertheless, it is by no means clear that casebooks match existing legal practice. Rather, they tend only to reflect practice as imagined by academics. Most academics have little sense of how many cases are litigated in different areas, or how much of the bar's attention is devoted to some questions rather than others. Nevertheless, legal academics create a sense - possibly too often derived from the opinions of the Supreme Court - concerning what issues are "hot" and therefore worthy of imposing on their students.

This need to map practice as the academic imagines it leads to an emphasis on "current problems." Here again court-centeredness - and particularly Supreme Court-centeredness - plays an important role. Hence, one sees a large amount of material devoted to areas in which legal doctrine changes virtually every Supreme Court Term. In the field of equal protection, for example, school desegregation cases have been followed by affirmative action cases, and now considerable attention seems to be focused on voting rights. One can trace the changing imaginations of academics by noting when certain issues begin to get a significant degree of space in constitutional law casebooks. One might look at the number of pages devoted to racist speech before and after R.A.V. v. City of St. Paul, $\sqrt{136}$ for example. Moreover, the rise of particular forms of legal scholarship (for example, feminist legal scholarship) can change the content of casebooks, even if the Supreme Court no longer hears a large number of gender discrimination cases. The pedagogical canon surely responds to driving forces in the academy and in legal culture generally as well as in the courts.

Even so, the notion of canonicity is usually posed against the issues of the moment and toward issues that are considered "timeless." This leads

power."' New York v. United States, 505 U.S. 144, 181 (1991) (quoting Coleman v. Thompson, 501 U.S. 722, 759 (1991) (Blackmun, J., dissenting)). Yet as Larry Kramer points out, few scholars, let alone members of the Supreme Court, have done enough work to justify any such confident pronouncements about the relationship between federalism and liberty. See Larry Kramer, Understanding Federalism, 47 VAND. L. REV. 1485, 1490, 1561 (1994). There are many different forms of federalism, and many different liberties that might be protected in greater or lesser degrees by these various forms. Moreover, if decentralization is the key to promoting liberty, it is by no means clear that power should be concentrated at the level of states rather than at the level of counties or municipalities.

Students who read these and other confident pronouncements are rarely informed just how dubious are many judicial descriptions of the world outside the courtroom. Perhaps one should not expect judges trained in law schools to be skilled in sound empirical and social analysis, but if so, this raises rather important questions about the judicial role.

136505 U.S. 377 (1992). 
to an inevitable conflict between covering the "leading cases" and covering problems that, in the view of the academic, are the truly important problems that lawyers and judges face (or should be facing).

The desire for timelessness is often related to the desire for "good teaching cases." Often this means cases and materials that raise what the teaching community considers to be important (and "timeless") issues of constitutional law. Nevertheless, the timelessness of the canon may be partially illusory; it may reflect the anxieties of the moment dressed up as timeless concerns. After all, the question of what is "important" and "timeless" is constructed by the legal culture, and changes over time. If the historical study of the canon teaches us anything, it is that timelessness isn't what it used to be.

The concept of timelessness, however, does lead us to the notion of imparting a tradition, which brings us to a different conception of canonicity. The cultural literacy canon consists of those cases and materials best designed to acculturate the student into the "tradition" of American constitutional discourse, and to introduce her to that which a member of a particular interpretive community should know. What is this interpretive community? It is an interpretive community as imagined by another interpretive community consisting of legal academics. Academics imagine a community of intelligent, educated, everyday lawyers, judges, and scholars. (We might compare this community with the imagined community of educated men and women that liberal arts education is supposed to produce.)

Everything that we have said about form versus content (what kinds of materials versus what kinds of issues) also applies to this tradition. Courtcenteredness, and in particular, U.S. Supreme Court-centeredness, is surely central to the current definitions of cultural literacy. Judging from existing constitutional law casebooks, apparently everyone needs to know Marbury v. Madison, ${ }^{137}$ but not Andrew Jackson's Bank Veto 138 the European Charter on Human Rights, or the German Basic Law.

This tradition, like so many others, is an "invented tradition." It comes into being at a particular point in history, and then regards itself as always

1375 U.S. (1 Cranch) 137 (1803). In fact, one of us (Levinson) confesses to having stopped teaching Marbury altogether because it costs far too much classroom time to teach it well relative to the gains that teaching it would produce. This confession is simply another way of articulating the quasiDarwinian point made earlier that all canons must be understood in "competitive" or "economic" terms. Canons are composed of materials that are engaged in a never-ending competition for space in the scarce resources of scholarly consciousness and for time in the limited hours that can be devoted to any given course. If we had infinite time and infinite memory there might be no need for canons; we could read and absorb everything. In fact we live in conditions of ever more imposing cognitive and temporal scarcity, where the very notions of "keeping up" with one's field or giving one's students a "comprehensive" overview of that field seem increasingly ludicrous. A teacher must decide what is worth teaching in a course that usually lasts no more than 42 hours. A casebook editor inevitably faces page limits that require, at best, vigorous editing of texts and, at worst, the ruthless exclusion of otherwise meritorious materials.

138 See BREST \& LEVINSON, supra note 23, at 49. 
having been there. We can uncover the inventedness of this tradition by investigating when certain materials enter and leave the canon of things every lawyer, judge, law student, or constitutional scholar should know, and connecting these changes to political and social issues of the time. Here are just a few examples of the questions one might ask about the canon of cultural literacy in constitutional law:

(1) What is the relationship between the rise of legal casebooks and the court-centeredness of the cultural tradition? In the nineteenth and early twentieth centuries, constitutional theory was more the province of political scientists than law professors 139

(2) When do law review articles become essential parts of the academic theory canon? We suspect the answer is only recently. When do treatises become important to the canon, and when do they begin to lose their importance? Joseph Story's and Thomas Cooley's treatises were surely influential during the nineteenth century, as were treatises by Williston, Corbin, and Wigmore in later years. However, student-edited law reviews have gradually replaced treatises as the major venue for scholarly commentary in our own time. ${ }^{140}$ Interestingly, constitutional law provides the one major exception: Laurence Tribe's American Constitutional Law 141

(3) When does Marbury become a central case in the cultural literacy and pedagogical canons? One guess is that Marbury gains particular importance in the twentieth century. It would be interesting to note the treatment of Marbury during the period leading up to the constitutional controversies over the New Deal when judicial supremacy was a major

139 This situation began to change with James Bradley Thayer, a law professor whose work on judicial review became highly influential. See Jay Hook, A Brief Life of James Bradley Thayer, 88 Nw. U. L. REV. 1, 5-6 (1993).

140 This change occurs as the audience for contemporary legal scholarship increasingly becomes fellow academics rather than judges and members of the practicing bar. The latter two groups now form the primary audience for legal treatises.

Mary Ann Glendon, in her critique of the contemporary legal academy, picks out "the declining prestige of the legal treatise" for special censure. Glendon, supra note 63, at 204. "Up to the mid1970s," Glendon writes, "treatises like [Louis] Loss on securities regulation, [Phillip] Areeda on antitrust, [Charles Alan] Wright and [Arthur] Miller on civil procedure, and [John H.] Wigmore on evidence were widely regarded as the highest form of legal scholarship. Their authors were the superstars of the legal academy." Id.

In Glendon's view, this happy state of affairs was disturbed in the late 1970s, when the legal academy was joined by "a new generation of professors" who "began to avoid purely 'doctrinal' scholarship" and turned away from older traditions of treatise writing. Id. As a result, Glendon asserts, "[t]he ratio of 'practical' to 'theoretical' essays published in leading law journals dropped from 4.5:1 in 1960 to $1: 1$ in 1985." Id. She contrasts her affection for the treatise tradition with the "harsh judgment" of Yale professor George Priest, who claimed in 1983 that treatise writing "has been cast off to practitioners" and that "[t]he treatise is no longer even a credit to those competing on the leading edge of legal thought." Id. at 204-05 (quoting George L. Priest, Social Science Theory and Legal Education: The Law School and the University, 33 J. Legal Educ. 437, 441 (1983)) (internal quotation marks omitted).

141 Laurence H. Tribe, American Constitutional Law (2d ed. 1988). 
concern. Surely McCulloch and Gibbons v. Ogden $\sqrt{142}$ must have assumed new importance during a time of expanding federal legislative power.

(4) Along the same lines, we might ask when Calder v. Bull143 which contains one of the earliest discussions of natural law - becomes central to the constitutional canon. Was it always seen as central or did its importance rise around the time of Griswold v. Connecticul144 or Roe v. Wade? Similarly, we suspect contemporary concerns are giving new prominence and importance to Justice Harlan's dissent in Lochner v. New York. The most famous dissent in Lochner has always been Justice Holmes's, peppered as it is with memorable aphorisms and quotable slogans. Yet while Holmes's canonical dissent offers little more than relentless majoritarianism, Harlan's careful consideration of the actual purposes and likely effects of legislation probably resonates more deeply with contemporary liberal constitutionalists searching for nuanced approaches to judicial scrutiny. In an earlier age trying to free itself from the excesses of Lochner, Holmes's aphoristic embrace of majority will sounded positively heroic and well worth canonizing. But in an age where unconstitutional conditions, positive liberties, affirmative action, and gay rights are on the scholarly agenda, Harlan's more judicious approach may seem increasingly relevant and attractive.

These questions presuppose a more general point: some cases and materials may languish in relative obscurity for decades or even centuries - except perhaps to a few cognoscenti - and then suddenly become central to the pedagogical, theoretical, or cultural literacy canons. This change in fortunes is usually not accidental, but is related to the constitutional problems of the present moment. Cases and opinions become timeless, in other words, when the time is right.

Indeed, several early casebooks did not begin with what many now consider the crown jewel in the constitutional canon, Marbury v. Madison; rather, they began with the amendment processes listed in Article V. ${ }^{145}$

14222 U.S. (9 Wheat.) 1 (1824).

1433 U.S. (3 Dall.) 386 (1798).

144381 U.S. 479 (1965).

145 See, e.g., Noel T. Dowling, Cases on American Constitutional Law 1-20 (1937) (beginning with "The Constitution; and The Amending Process"); Oliver Peter Field, A Selection of CASEs AND Authorities on Constitutional Law 1-18 (1930) (beginning with "The Formulation and Modification of the Constitution of the United States"); JAMES PARKER HALL, Illustrative CASES ON CONSTITUTIONAL LAW 1-17 (2d ed. revised and enlarged 1927) (beginning with a section on the "Establishment and Amendment of Constitutions"). One should compare these casebooks with the "Harvard" casebook published during the heyday of the Legal Process era, see 1 Paul A. Freund, Arthur E. Sutherland, Mark DeWolfe howe \& Ernest J. Brown, Constitutional Law: CASes and Other Problems 3-39 (1954). This casebook begins, as most contemporary casebooks do, with the historic basis of judicial review. By his fourth edition in 1950, Dowling had dropped the introductory remarks on amendment and replaced them with the "Origin of [the] Doctrine of Judicial Review." Noel T. Dowling, Cases on Constitutional Law 1-69 (4th ed. 1950). Interestingly, and symbolically, this material appears even before the text of the Constitution itself. For the successor to Dowling's casebook, see NoEL T. Dowling \& Gerald GunTHER, CASES and Materials on Constitutional LaW (7th ed. 1965), which appears in its latest incarnation as 
This may reflect the interests of political scientists, who still dominated the field in the early part of the century. It may also reflect a more Continental way of thinking about constitutional law: the student should begin with structural features and the rule of recognition, asking first how we know something is part of the Constitution and how one adds things to the Constitution. In many of these early casebooks, individual rights issues are considered secondary, 146 whereas they are considered central to American constitutional law today.

\section{Pedagogy and Academic Theory}

Although the pedagogical and cultural literacy canons are conceptually distinct from the canons of academic theory, they surely affect the structure of normative constitutional theory. The selection of cases and materials in casebooks and other teaching materials both reflects and perpetuates particular (some would say outmoded) understandings of legal issues. Through organizational decisions, the pedagogical canon can direct our attention toward certain problems and issues and away from others, or cause us to see certain situations as paradigmatic and others as secondary or inconsequential.

The treatment of the First Amendment is a good example. For many years, the paradigm of seditious libel by a political dissenter has been taken as the canonical example for free speech theory; this conception gains its apotheosis in Brandenburg v. Ohio 147 in which the Supreme Court laid down doctrines about seditious advocacy that strongly protect dissenting speech. ${ }^{148}$ Few teachers who concentrate on the classic canon of free speech cases seem to acknowledge that extremely few dissenters today face the prospect of criminal punishment for what they say. This may be the result of liberal legal doctrines themselves or it may be the result of deeper changes in our culture. In any event, the truly central First Amendment controversies of our era - campaign finance, government speech, broadcast regulation, and unconstitutional conditions - do not fit easily into the paradigmatic example of a lone dissenter spewing out unpopular opinions. As a result, casebooks have found no completely adequate way of dealing with them. ${ }^{149}$ A particularly pronounced example

GUNTHER \& Sullivan, supra note 52. The discussion of constitutional amendments and Article V has by now been relegated to a single, lengthy footnote on "Other Congressional Powers." Id. at 250 n.1.

146 See, e.g., Hall, supra note 145, at xiii-xiv (table of contents devoting primary coverage to structural issues); HenRy RothtsChaEFER, CASES ON CONSTitutional LAW vii-viii (1932) (same).

147395 U.S. 444 (1969) (per curiam).

148 See id. at 447.

149 In contrast, the problems of racist speech and pornography have been assimilated with much less difficulty into the organization of the pedagogical canon. They fit easily into the standard paradigm of the lone individual (or group of individuals) saying things that others do not like. After all, one of the earliest racist speech cases was Beauharnais v. Illinois, 343 U.S. 250 (1952), and even Brandenburg itself might be viewed as a racist speech case. Indeed, the most prominent racist speech case of our era, R.A.V. v. City of St. Paul, 505 U.S. 377 (1992), is an old-fashioned criminal prosecution. In like 
of this phenomenon occurs in Gerald Gunther's popular casebook, which for many years divided the world of free speech into subversive advocacy, time, place, and manner regulation, symbolic expression, and "Additional Problems." 150 When almost all of the key free speech issues of our time have become "additional problems," one senses that the central theoretical approaches to the First Amendment desperately need rethinking.

A second kind of effect on theoretical imagination stems from the increasing specialization of constitutional law resulting from the explosion of constitutional law cases and claims of constitutional rights that must be protected by judicial review. We might think of this as the victory of the exceptional cases described in footnote four of United States v. Carolene Products Co. 151 over the normal case of judicial review described in the text of that opinion.152 The more opportunities that exist for judicial review of individual rights, the more specialization occurs.

For example, especially after the 1960 s, constitutional law casebooks started to carve off the criminal procedure materials for reasons of space. At present only the casebook edited by William Lockhart, Yale Kamisar, Jesse Choper, Steven Shiffrin, and Richard Fallon retains a substantial amount of these materials, largely, we suspect, because Professor Kamisar, a noted expert on criminal procedure, is one of the editors. 153 Criminal procedure, in short, has unfortunately become a specialty that is no longer taught by most ostensible "experts" on constitutional law (including ourselves). This has two unfortunate effects.

First, constitutional theorists may tend to neglect the many instances of constitutional interpretation that occur in criminal procedure cases, and that

fashion, casebook authors can (and do) simply insert discussions of feminism and pornography after the traditional materials on obscenity. See, e.g., GunTHER \& Sullivan, supra note 52, at 1126-55. We do not doubt that it might be better to treat these materials in a different way - for example, as part of the study of the Equal Protection Clause. Our point is rather that casebooks have had much less trouble working them into a traditional schema, even if that schema is ultimately mistaken.

150 Gerald Gunther, Cases and Materials On Constitutional Law 1105-1545 (10th ed. 1980). These "additional" First Amendment problems included defamation, obscenity, prior restraint, commercial speech, labor picketing, freedom of association, and campaign finance. See id. at lxviiilxxiv. However, Gunther shrewdly placed Red Lion Broadcasting Co. v. FCC, 395 U.S. 367 (1969), and Miami Herald Publishing Co. v. Tornillo, 418 U.S. 241 (1974), with the public forum cases. See GUNTHER, supra, at 1302-05.

151304 U.S. 144,152 n.4 (1938).

152 This is the argument of J.M. Balkin, The Footnote, 83 Nw. U. L. REV. 275, 301 (1989).

153 The Lockhart casebook is also unique in continuing to include substantial material on capital punishment. See Lockhart, Kamisar, ChOper, Shiffrin \& FAllon, supra note 52, at 555-81. Indeed, among the other standard casebooks, only BREST \& LEVINSON includes as a major case McCleskey v. Kemp, 481 U.S. 279 (1987), which rejected a challenge to death penalty procedures on the ground of racial discrimination. See id. at 290-91; BREST \& LEVINSON, supra note 23, at 678-86 (edited version of McCleskey). It says much about the current canon that the index entry under "death" in the Gunther \& Sullivan casebook directs the reader to "Right to die." GunTHER \& Sullivan, supra note 52, at I-2. This is, no doubt, because the right to die fits easily under the categories of substantive due process that are still central parts of the pedagogical canon, while the right to be free from death is conceptualized under the Eighth Amendment's Cruel and Unusual Punishments Clause and hence is relegated to courses on criminal procedure. 
may affect or help predict judges' and Justices' views in other types of cases. For example, the dispute between Justices Black and Frankfurter over incorporation was largely waged in the area of criminal procedure. ${ }^{154}$ In our own day, Justice Scalia's interpretations of the Confrontation Clause seem linked to his formalist interpretations of other parts of the Constitution 155

Second, if constitutional theorists do not pay attention to criminal procedure issues, these issues will tend to be thought of as administration of justice issues rather than questions of constitutional interpretation. The criminal procedure amendments will, in short, be written out of the legal imagination of an entire generation of constitutional scholars 156

We have witnessed in our own time the "shrinking" of the Bill of Rights so that in the imagination of constitutional law professors it encompasses only the First Amendment, the Takings Clause, and the Due Process Clause. This way of thinking destroys the sense that the component parts of the Bill of Rights are interrelated.157 Only specialists in criminal procedure follow and critically comment on the Supreme Court's interpretation of large parts of the Bill of Rights. Hence, there is a loss of a common culture of discussion among legal scholars about the Supreme Court's work in interpreting the different parts of the Constitution. A related problem may now be appearing on the horizon as free speech courses are increasingly taught separately from equal protection and due process courses.

Indeed, even within the remaining areas of the constitutional law casebook, certain parts of the Constitution are treated as peripheral and are often left out of courses (for example, interstate taxation and intergovernmental immunity) or are taught only in specialized courses (for

154 See, e.g., Rochin v. California, 342 U.S. 165 (1952); Adamson v. California, 332 U.S. 46 (1947).

155 See George Kannar, The Constitutional Catechism of Antonin Scalia, 99 YALE L.J. 1297, 133034, 1355 (1990).

156 But see Akhil Reed Amar, The Constitution and Criminal Procedure (1997) (approaching the criminal procedure provisions of the Bill of Rights through the lenses of textual and structural constitutional interpretation).

157 Akhil Amar's work on the Bill of Rights is one of the few recent attempts to read the amendments together as part of a single Constitution. See Akhil Reed Amar, The Bill of Rights: CREATION AND RECONSTRUCTION (forthcoming 1998).

Similarly, one of us (Levinson) believes that a mindless textualism has led professors who teach "the First Amendment" to include subversive advocacy and federal aid to parochial schools in the same constitutional law course - because both the Free Speech Clause and the Religion Clauses appear in the text of that amendment - while ignoring the profoundly interesting implications of the Second Amendment. These implications should be especially important for anyone who emphasizes the "checking value" that underlies the free speech and press provisions of the First Amendment, for there can be little doubt that many members of the founding generation viewed popular possession of arms as the ultimate "check" on corrupt governments. See Sanford Levinson, The Embarrassing Second Amendment, 99 Yale L.J. 637, 648-50 (1989); see also L.A. Powe, Jr., Guns, Words, and Constitutional Interpretation, 38 WM. \& MARY L. REV. 1311 (1997) (elaborating possible connections between First and Second Amendment doctrines). 
example, voting rights). 158 The marginalization or exclusion of certain features of the Constitution may well affect which paradigms dominate discussions of constitutional theory and which shape the imaginations of constitutional scholars.

In other words, as specialization increases apace, scholars who do constitutional "grand theory" may view only a narrower and narrower part of constitutional law as their job to explain. If so, their theoretical views may become increasingly parochial, or increasingly subject to the blinders and limitations that arise whenever a theory is tested against only a limited set of situations.

Often the choice of cases and materials in a constitutional law casebook reflects a narrative about the development of the Constitution and constitutional law. For example, the casebook author can present materials as the historical evolution of doctrine toward a particular goal, the "present situation." This present situation can be portrayed as either a good thing or a bad thing, but the point of the narrative is to envision constitutional law as working toward a certain state of affairs. The evolution of constitutional law can be a story of progress or one of gradual decline from an earlier, golden era, whether it be the era of the Founders, Reconstruction, the New Deal, or the halcyon days of the Warren Court. 159 One can arrange cases and materials as an ongoing dialectic of principle and counterprinciple, struggling with each other in the materials of the law 160 Finally, if one wants to take a strongly genealogical approach, one can simply present the cases as reflecting the political and cultural anxieties of their times, showing how the law has been different before and no doubt will be different again. Every casebook tells a story, if we will only listen to it; indeed, it is almost impossible to organize a casebook that tells no story at all.

\section{Expanding the Canon}

In the debates over canon formation in the humanities, the contestants have disagreed less about whether canonical writers like Shakespeare or Homer should be retained, and more about whether the canon should be expanded to include new materials written by women, minorities, or nonWestern European writers. The analogous question in law is whether students should be exposed to "marginalized voices" in their study of law. The expression is placed in quotation marks because its meaning is essentially contested. To be sure, examples of marginalized voices in

158 These new courses, in turn, give rise to new and more specialized casebooks. See, e.g., SAMUEL Issacharoff, Pamela S. Karlan \& Richard H. Pildes, The law of Democracy: Legal Structure of the Political Process (1998).

159 See Robert W. Gordon, The Struggle Over the Past, 44 CLEv. ST. L. Rev. 123, 127-31 (1996).

160 An excellent example is Friedrich Kessler \& Grant Gilmore, Contracts: Cases and MATERIaLs (2d ed. 1970), which appears in its most recent incarnation as FrIEDRICH KessLer, Grant Gilmore \& ANthony T. Kronman, Contracts: Cases and Materials (3d ed. 1986). 
contemporary constitutional discourse might include women, homosexuals, and racial and ethnic minorities. But marginalized groups might also include laypersons of whatever race, gender, or sexual orientation, for their lack of professional status means that they have almost always been excluded from serious constitutional debates. The student of the canon should ask to what degree this exclusion is parochial or unfair.

Marginalization is a normative as well as a descriptive matter. Many people have been forgotten or marginalized in present-day legal discussions. Any reviser of subject matter canons must choose among them and must also be prepared to offer convincing reasons for her choice. To the narratives of slaves and suffragettes one might consider adding the following marginalized voices: the Mormon settlers of Utah, who were forced to abandon important tenets of their religion (including polygamy) so that the Utah Territory might enter the Union; 161 contemporary religious fundamentalists, ${ }_{162}$ who are often despised or treated with condescension by secular America; members of the contemporary "militia" movement, who have developed distinctive views about the interpretation of constitutional and common law; 163 William Lloyd Garrison, who argued that the North should secede from the South because the Constitution was "a covenant with death and an agreement with hell"; 164 and John C. Calhoun, who was not only a staunch supporter of slavery, but also a constitutional theorist of great imagination whose doctrine of concurrent majorities is strikingly relevant to today's debates over voting rights and the constitutionality of race-conscious redistricting 163 Several of these examples may suggest that marginality is sometimes well-deserved; yet one can hardly deny that decisions about which of these marginalized groups should be recognized and which consigned to oblivion are heavily politicized.

"Marginalization" includes issues of form as well as content. To the law professor's court-centered mind, the most obvious examples of "new" materials that might be added to the legal canon are older, neglected U.S. Supreme Court cases; thus, people might debate whether slavery cases like Prigg v. Pennsylvania or The Antelope 166 should enter the pedagogical canon, and, conversely, whether anything is really lost by dropping

161 See Davis v. Beason, 133 U.S. 333, 348 (1890); Murphy v. Ramsey, 114 U.S. 15, 42-47 (1885); Reynolds v. United States, 98 U.S. 145, 166-67 (1878); Thomas G. AleXANDER, Mormonism IN TRANSITION: A HiSTORY OF THE LATTER-DAY SAINTS 1890-1930, at 3-15, 60-73 (1996) (detailing the persecution of Mormons); LeOnard J. ArRington \& Davis BitTon, The Mormon ExPerience: A HISTORY OF THE LATTER-DAY SAINTS 185-205 (2d ed. 1992) (same).

162 See, e.g., Mozert v. Hawkins County Bd. of Educ., 827 F.2d 1058 (6th Cir. 1987).

163 See, e.g., Susan P. Koniak, When Law Risks Madness, 8 CARdozo Stud. L. \& Literature 65, 67-68 (1996); David C. Williams, The Militia Movement and the Second Amendment Revolution: Conjuring with the People, 81 Cornell L. Rev. 879 (1996).

164 See MERRILL, supra note 22, at 205.

165 See, e.g., 4 The Works of John C. Calhoun 338-47 (R. Crallé ed., 1851).

16625 U.S. (12 Wheat.) 546 (1827). 
taxation of interstate commerce cases or even regulation of pornography cases from the first-year course to make room. Yet an equally important question concerns whether court decisions should be replaced or supplemented by nonjudicial materials. One of us (Levinson) co-edits a casebook that has consciously chosen to eliminate quite a few of the standard cases 167 while including speeches by James Madison and Frederick Douglass, Andrew Jackson's veto of the bill renewing the charter of the (Second) Bank of the United States, an opinion of the United States Attorney General concerning the delivery of abolitionist mail in Mississippi, and excerpts from the Lincoln-Douglas debates about the proper respect due the Court's decision in Dred Scott 168

One reason to include the Lincoln-Douglas debates is that they are important to cultural literacy. But they also raise fundamental issues about constitutional theory and the role of canonical materials in undergirding one or another approach to the Constitution. We believe that it is vitally important to emphasize the crucial role that nonjudicial officials (and, indeed, the citizenry at large) play in constitutional interpretation. Few Supreme Court Justices have had as much theoretical and practical influence on our constitutional order as Abraham Lincoln. Yet because most contemporary casebooks and courses are so unrelentingly U.S. Supreme Court-centered, they offer a highly distorted understanding of the American constitutional system to the hapless students exposed to them. These students will almost inevitably end up believing that constitutional interpretation is the exclusive province of the judiciary - and particularly the Supreme Court — both as a theoretical and an empirical proposition. As a theoretical proposition, this is pernicious. As an empirical proposition, it is preposterous. This willful ignorance of nonjudicial interpreters is a form of marginalization quite different from those we are accustomed to, but it is no less serious 169

167 Jerry Goldman's recent survey notes that BREST \& LEVINSON has by far the fewest cases (98) of any of the major law school casebooks. The Gunther casebook has the most (129), and the Stone casebook is not far behind with 122. See Goldman, supra note 43, at 4.

168 These choices reflect the view that these materials are far more canon-worthy than, say, Carter $v$. Carter Coal Co., 298 U.S. 238 (1936), a hoary relic of the Bad Old Lochner-era Court and one of the cases omitted in the third edition of BREST \& LEVINSON.

Because BREST \& LEVINSON no longer devotes full coverage to the First Amendment, omitted materials include such classics as New York Times Co. v. Sullivan and the entire corpus of cases involving pornography and election finance. However, the omission of the First Amendment has other repercussions as well. Both of us feel that election finance is one of the most important issues in contemporary constitutional law, and thus the omission of First Amendment challenges to campaign finance legislation is a clear example where pedagogical interests in introducing students to the study of constitutional law and constitutional interpretation must trump the concerns of academic theory and the interests of practicing lawyers.

169 Indeed, no casebook, including BREST \& LEVINSON, has paid sufficient attention to the problem of amendments (whether legal or illegal) outside of Article V. This question, central to Bruce Ackerman's important recent work, see ACKERMAN, FoundATIONS, supra note 103, at 53-54; ACKerman, Transformations, supra note 103 , has yet to be assimilated adequately into the constitutional canon. Although all casebooks spend countless pages on varying interpretations of the 
Almost equally neglected in most casebooks is the phenomenon that, after all, explains the events of 1861 to 1868: the presence within the United States of a legally sanctioned system of chattel slavery. We think there are many reasons to include materials on slavery in the canon of constitutional pedagogy.170 One purpose, though, is simply to point out that the American constitutional tradition - and, beyond that, the notion of the rule of law itself - has often been intertwined with and used to promote the enforcement of evils like slavery. In the antebellum period a formative period of American constitutional thought - competent lawyers were quite able (and indeed were expected) to offer any number of legal arguments concerning slavery, just as they offered arguments about the constitutional status of navigation, the immigration of paupers, or the regulation of interstate commerce. Focusing on slavery shows that the record of the Constitution and of constitutional lawyers is considerably more mixed regarding the issue of slavery than many admirers of the Constitution might wish to concede. More generally, students must recognize, despite their natural admiration for the Constitution, that the constitutional tradition is full of racism and sexism fully responsive to what Holmes unforgettably labeled "the felt necessities of the time." When these "felt necessities" included the ruthless suppression of what we in our own era consider "basic human rights," the "authoritative interpreters" and elite lawyers ensconced in Washington and elsewhere had no difficulty whatsoever in accommodating their interpretations of the Constitution to those necessities.

This justification for the inclusion of materials on slavery is historicist. It hopes to show the student that at different points in history constitutional arguments have been evaluated and constructed very differently and that the Supreme Court has often changed its mind about what counts as sound constitutional analysis. Moreover, the approach is also critical, for it seeks to remind students that, while purporting to speak in the name of the Constitution, the Supreme Court has often done very wicked things whose effects are still with us today. If we recognize the Constitution's checkered

Fourteenth Amendment, none devotes more than scant attention to the problematic status of the Fourteenth Amendment's ratification. In order to guarantee a two-thirds majority in favor of the Amendment, the Reconstruction Congress refused to seat southern senators and representatives. See id. at 99-119. Moreover, Congress refused to reseat those southern congressional delegations or to recognize the legitimacy of southern state governments - including governments thought necessary for ratification of the Thirteenth Amendment - until those governments ratified the Fourteenth Amendment. See id. Ackerman, in contrast, argues that the deepest single question of American constitutional theory is how to develop a truly satisfying account of the legitimacy of this necessary yet problematic Amendment. See id. We think that confronting Ackerman's questions seriously would require disruptions in all of the canons of constitutional law - pedagogical, cultural literacy, and theoretical.

170 See generally Levinson, supra note 115, at 1094-95 (discussing justifications for including materials on slavery in law school constitutional law classes).

171 O.W. Holmes, JR., The Common Law 5 (Mark DeWolfe Howe ed., Harvard Univ. Press 1963) (1881). 
past, we can better understand that the constitutional interpretations of our own time may also be complicit in evils many of us would rather not confront 172

At first glance, this critical or historicist approach appears to have much in common with feminist and minority critiques of the literary canon; these critiques also seek to expose social injustice through expansion of the canon. Yet their approaches differ in several important respects. In literature, constructors of the canon are much less likely to dredge up forgotten racist novels of the nineteenth century for inclusion in the canon than to focus on demonstrating the inherent racism of currently accepted parts of the received literary canon and to suggest the inclusion of African-American writers unjustly neglected. In like fashion, feminist literary theorists might be interested in sexist or male supremacist elements common in the popular literature of the past, but they would probably not argue for the permanent inclusion of sexist literature in the canon in order to encourage people to read and be challenged by it. Thus, the purposes of expansion are quite different in law and in literature. Both a constitutional historicist and a feminist literary critic would attempt to reveal the history of sexism or racism in their respective fields. However, the result in the case of law would be to enshrine these examples in the canon so that students would have to confront them and learn about the historicity of constitutional views of what is just and right. By contrast, a feminist literary critic might discard these texts after revealing them as examples of the injustices of the past (and as continued in the ideology of the present). Like the inclusion of slavery in the constitutional canon, the feminist attack on the literary canon is designed to reveal ideology. But it is done for different reasons and with different consequences for the educational process.

\section{E. The Symbiosis of Theories and Canons}

The academic theory canon does not include all of the cases and materials that lawyers and courts regularly use in defending constitutional arguments. These materials tend to be comparatively recent and driven by specific doctrinal considerations. Rather, the academic theory canon consists of cases and materials that are sufficiently important to the arbiters of this canon (legal academics) that any theory of constitutional law must account for them. Here the canon is like a set of doctrinal dots that any theory of constitutional law must connect. Thus, we might also call it the "theory construction" canon. It is the canon used to construct and test relevant theories of constitutional law and constitutional adjudication. The classic example of a "must explain" case, of course, is Brown v. Board of Education.

172 See J.M. Balkin, Agreements with Hell and Other Objects of Our Faith, 65 FordHAM L. Rev. 1703, 1720 (1997). 
The construction of an academic theory canon is accompanied by the formation of an "anti-canon" of cases that any theory worth its salt must show are wrongly decided. Examples are Lochner v. New York, Plessy v. Ferguson, and Korematsu v. United States. Our notions of what is canonical tell us that we have to justify Brown (a good case) and explode Lochner (a bad case). In contrast, no one thinks it as important to explain why Bunting v. Oregon $\sqrt{173}$ or Hebe Co. v. Shan $\sqrt{174}$ are rightly or wrongly decided 175 Indeed, these twin notions of normative canonicity and anticanonicity are also central to the pedagogical and cultural literacy canons. Cases become important to teach and remember because they serve as the icons (and demons) of an invented constitutional tradition.

The "canonical" problems of justifying Brown or decrying Lochner are presented repeatedly as we are educated in constitutional law. Doctrinal heroes and villains appear to us already identified and waiting for us to confront them. Indeed, the standard constitutional law course might well be understood as organized around the ritual justification and demonization of specific canonical cases. (How many constitutional law courses have taken as their central theme "The Ghost of Lochner?") One sometimes feels that all of modern constitutional theory is driven by a desire to justify (or condemn) five cases (and we all know which ones they are).

One of the most interesting features of the academic theory canon lies precisely in its tendency to force us to recognize certain cases as "heroes" or "villains" - so that a libertarian can safely be considered "out of the mainstream" if she, like Richard Epstein, actually approves of a case like Lochner. This is a point of no small importance. It reveals the canon and canonicity as vehicles for the normalization of beliefs and interpretive assumptions, and hence as instruments of social control for the relevant interpretive community. A constitutional theorist has to explain why Dred Scott or Plessy v. Ferguson is bad constitutional law (and not just morally appalling) or she is out of the game ${ }^{176}$ Thus, central to any struggle over the constitutional canon is the demarcation of the icons and the demons of constitutional law, and inherent in this demarcation is the normalization of positions that can then be used to normalize discourse (and thought) about constitutional law.

\footnotetext{
173243 U.S. 426 (1917).

174248 U.S. 297 (1919).

175 Bunting v. Oregon upheld a cap on working hours and required time-and-a-half pay for overtime. See Bunting, 243 U.S. at 438-39. Hebe Co. v. Shaw upheld a regulation of adulterated foodstuffs. See Hebe, 248 U.S. at 302-03. Both cases are interesting because they were decided during the Lochner era, when the Supreme Court was generally thought to be hostile to such legislation.

176 Michael Klarman has offered an extremely provocative critique of such "normativism" in constitutional scholarship. See Michael J. Klarman, Rethinking the Civil Rights and Civil Liberties Revolutions, 82 VA. L. REv. 1, 25-31 (1996). Mark Graber has recently noted that "[c]ontemporary constitutional theory rests on three premises[:] Brown v. Board of Education was correct, Lochner v. New York was wrong, and Dred Scott v. Sandford was also wrong." Mark A. Graber, Desperately Ducking Slavery: Dred Scott and Contemporary Constitutional Theory, 14 CONST. COMMENTARY 271, 271 (1997).
} 
Indeed, the most remarkable evidence of this normalization concerns the constitutional text itself. Not only are non-Supreme Court materials relentlessly excluded from the teaching canon and the cultural literacy canon, but it is by no means clear that the entire text of the Constitution itself is necessarily part of these canons. There are significant parts of the constitutional text that no one in the legal academy thinks it very important to explain; within this interpretive community these portions have for all intents and purposes been read out of the Constitution. Candidates might include the Second Amendment, the Republican Form of Government Clause, and the Privileges or Immunities Clause of the Fourteenth Amendment 177

One challenges the academic theory canon by offering a counter-canon - a different set of cases and materials. One offers a counter-canon (pedagogical or cultural literacy) to rediscover cases and materials and parts of the constitutional text that have been neglected, that point in opposite directions, or that are embarrassing to currently fashionable academic theories created to explain the existing canon.

Thus, one important purpose for expanding the pedagogical canon or the cultural literacy canon is to critique existing normative theories of constitutional law. That is because constitutional theories tend to be adapted to solve certain canonical problems: for example, legal process theories were adapted to address concerns of federalism and separation of powers. Yet there is often an awkward fit between these theories and different sorts of problems. So it can be an amusing as well as an instructive exercise to apply a well-known theory - for example, the principle of institutional competence, the notion of law as integrity, or Carolene Products-style theories of process protection - to a "different" area of constitutional adjudication - for example, slavery. When one starts talking about making slave law the best it can be, preserving democratic deliberation about the regulation of slavery, or the relative importance of state versus federal competence in the regulation of slaves, one begins to see the limitations and narrowness of contemporary constitutional theories.

In particular, these thought experiments help us see how constitutional theories actually tend to avoid putting the basic justice of the legal system

177 Among the words not discussed in most constitutional law courses are those of the Preamble, which, among other things, demand that the Constitution be employed to promote "the general Welfare" and "to establish Justice." U.S. Const. preamble. It is possible that the reason why the Preamble has not figured more prominently in constitutional interpretation is that it does not appear to be selfexecuting. However, this begs the question why it could not be so interpreted. Even if the Preamble does not contain any new rights or powers, it might, like the Ninth and Tenth Amendments, be considered a rule of interpretation that applies to the entire document. Perhaps the best analogy is to the Second Amendment, which contains a clause about the necessity of well-ordered militias that presumably explains why the right to bear arms is guaranteed. In like fashion, one might argue that the provisions of the Constitution are to be liberally interpreted to promote the goals set forth in the Preamble. 
into question by offering intricate and intellectually demanding forms of legal analysis as a substitute for and a diversion from potentially delegitimating inquiries about our constitutional system. When these theories are applied to universally condemnable practices, we more clearly understand how they encourage a flight from substance.

Thus, it should not surprise us that leading constitutional theories exist in a symbiotic relationship with the pedagogical and cultural literacy canons whose materials they describe and justify: normative constitutional theories help construct what parts of the constitutional tradition to explore and emphasize (because these theories work best with respect to these areas). At the same time, the pedagogical and cultural literacy canons tend to give these constitutional theories greater purchase and plausibility than they might otherwise have. The construction of the pedagogical and cultural literacy canons allows contemporary constitutional theories to escape certain embarrassing moments and proceed with their project of legitimation.

\section{CONCLUSION}

We began this Commentary by asking whether Frederick Douglass's Glasgow Address should become part of the pedagogical canon, perhaps in juxtaposition to Roger Taney's infamous Dred Scott opinion. We think that it should; indeed, we think that it is a particularly good example of how the constitutional canon might be expanded.

In saying this, we fully recognize that we cannot create or enforce a constitutional canon by ourselves. That task belongs to no single person or set of persons. Rather, canons are made by all of us, just as our ways of thinking are shaped by them in turn. Even so, we are participants in building the canon that we will bestow upon the next generation, and so we have as much right as duty to offer our own views, in the hope that they will influence others. Thus, we gladly affirm that Douglass's Glasgow Address deserves a place in the canons of constitutional pedagogy; indeed, we think it is something that every educated lawyer and every constitutional theorist should know. We believe this for three reasons.

First, Douglass's speech is important because it is made by a person who is not a member of any governmental body or even a professionally trained lawyer. In this sense, it reveals to the student that all Americans, even those who have heretofore been excluded from the People, have the right, and the duty, to interpret the Constitution and to decide for themselves what that document means.

Second, Douglass's speech is important because it is made by a prominent figure in a social movement, the antislavery movement. We think American constitutional development is too often taught as the history of decisions by judges who, even if they are to some degree influenced by the events around them, nonetheless move either in response 
to autonomous legal norms or in ways that are ultimately idiosyncratic and mysterious. Alternatively, the history of constitutional law is taught as the history of great jurists who show the rest of us the way through their wisdom or their folly. Imagining constitutional development in this way neglects the fact that constitutional changes - including changes in constitutional interpretation - are often the result of mass political action, which is later recognized and sanctified by various legal and judicial elites. 178

The members of the International Workers of the World (IWW) had far greater prescience about the meaning of the First Amendment than did Oliver Wendell Holmes or even Louis Brandeis.179 Conversely, the standard narrative that emphasizes the Supreme Court's "leadership" in Brown v. Board of Education usually overlooks the limited impact of that opinion in the decade following it 180 It also ignores the significance of President Truman's willingness to defy American military leaders in 1947 and to order the desegregation of the armed forces. The 1948 election, among other things, confirmed that the general electorate - even if not that in the Deep South - was willing to reward a President who committed himself to civil rights. And, of course, Truman's willingness to make such decisions itself reflected changes in American political demographics and the rise of an increasingly activist black constituency.

Legal academics who look to the Supreme Court to "lead" public opinion must explain, among other things, why the President would nominate, and the Senate confirm, persons significantly out of step with the conventional wisdom at the time of their selection. We strongly suspect that public opinion much more often leads the Supreme Court even if in suitably complex ways - than the other way around.181 If we paid more attention to the empirical realities of American politics - an attention that is rare in any constitutional law casebook - we might have a very different view of the so-called "countermajoritarian difficulty" as the central theoretical issue of constitutional law 182 Legal academics often

178 For a discussion of the central role of social movements in shaping elite discourse about the Constitution, see J.M. Balkin, The Constitution of Status, 106 YALE L.J. 2313, 2338-42 (1997).

179 See David M. Rabban, Free Speech in Its Forgotten Years 77-128 (1997). Rabban states:

Commentary generated by the IWW free speech fights refutes the conventional understanding that Americans before World War I did not pay much attention to the meaning of free speech. ... This commentary overwhelmingly took place outside the judicial system. Most of it was more sophisticated analytically, and more sensitive to free speech concerns, than typical judicial decisions of the period ....

Id. at 128

180 See, e.g., Gerald N. Rosenberg, The Hollow Hope 39-41 (1991).

181 As Mr. Dooley once put it, "no matter whether th' Constitution follows th' flag or not, th' Supreme Coort follows th' iliction returns." Finley Peter Dunne, Mr. Dooley AT His Best 77 (Elmer Ellis ed., 1938).

182 Cf. Mark A. Graber, The Nonmajoritarian Difficulty: Legislative Deference to the Judiciary, 7 Stud. Am. Pol. Dev. 35, 37 (1993) (internal quotation marks omitted) (noting that the Court often is willing to resolve issues delegated to it by a grateful Congress unwilling to pay the political costs of resolution). 
ask themselves whether the courts should defer to or wait for the creation of new rights by legislation or amendment. What they should ask themselves instead is whether judicial decisions do not already reflect the political and ideological struggles playing out in the larger culture, translated into the professional discourse of the law.

Today, homosexual rights are on the agenda of the federal courts not because judges locked up in their ivory towers have decided that it is time to start talking about them, but because of a revolution in the social meanings of heterosexuality and homosexuality precipitated by the growth of a movement for homosexual rights following the Stonewall riots. Nor is it irrelevant that an increasing number of political officials, both elected and appointed, are willing to acknowledge being gay or lesbian. Social movements play a key role in influencing the development of culture, and hence in changing social meanings so that judges can later "discover" new rights in the Constitution, often making arguments first offered by dissidents outside the bounds of professional discourse. Douglass's speech reminds us that the interpretation of the Constitution, while provisionally in the hands of professionally trained elites, ultimately rests in the hands of the larger political culture of the United States, or to put it in more storied terms, it rests in the hands of the people.

Third, Douglass's speech deserves a place in the constitutional canon - along with Dred Scott and Prigg v. Pennsylvania - because it brings home to the student, to the practicing lawyer, to the citizen, and to the legal academic a central question of constitutional law, a question that creates enormous dissonance in our souls, a question that we and generations before us have tried in countless ways to avoid asking or confronting: how can a person be faithful to a Constitution in a country with deeply unjust conditions that claims that those conditions are justified or permitted by that very text? What shall we do if we discover that the Constitution itself might be an evil document that keeps evil in place, if we suspect that it might even be "a covenant with death and an agreement with hell?"

Should we, like William Lloyd Garrison, declare the Constitution to be such an agreement and refuse to enforce it? Should we, like Roger Taney, the author of Dred Scott, embrace current conditions, and the Constitution that permits them, because we are upholding the rule of law and the intentions of the Framers? Should we, like Joseph Story, the author of Prigg v. Pennsylvania, return the escaped slave to her master, enforce a constitutional bargain with slave states that we believe to be deeply unjust, precisely because it is a bargain and because it is necessary to avoid some even greater calamity - namely civil war? Or should we, like Frederick Douglass, refuse to acknowledge evils in the Constitution while denouncing the evils done in its name? Should we construe the Constitution to permit evil, knowing that it may be evil, or perhaps convincing ourselves that it is not so evil after all? Or should we construe the Constitution "strictly" in favor of our vision of human rights and 
justice, regardless of the original understandings, or even the current consensus about its meaning, in the hope that the Constitution, and the country, may someday become what it presently promises to be?

Our reasons for including figures like Douglass and Garrison - as well as Taney and Story - in our own courses on constitutional law reveal our sense of what is most important about the task of legal pedagogy. We are teachers of law, not of justice, and yet the question of justice - and law's persistent failure to attain it - can never remain out of our minds for long. When we teach our students law, we introduce them to a world.183 It is a world that they will inhabit for many years to come, one that we hope will enable them, not only as lawyers, but as citizens, to lead better, more worthwhile lives. But our very entry into such a world is simultaneously the successful inculcation of a canon, a rule of practice and a discipline of thought that shapes our imaginations, colonizes our consciousness, and helps make us, for better and for worse, the kind of people that we are. To imagine that one can escape this canonicity is a fantasy. To imagine that we can exercise a greater degree of selfconsciousness about the canons that constitute our professional lives is not. It is time that we did so.

183 Or, as Robert Cover would have said, we make them part of a nomos. See Robert M. Cover, The Supreme Court, 1982 Term - Foreword: Nomos and Narrative, 97 HARV. L. REv. 4, 4 (1983). 